\title{
A Photo Essay of a Failed Reform
}

Beida, Tiananmen Square and the Defeat of Deng Xiaoping in 1975-76

\section{David Zweig}

\section{OpenEdition}

\section{Journals}

\section{Electronic version}

URL: http://journals.openedition.org/chinaperspectives/6893

DOI: 10.4000/chinaperspectives.6893

ISSN: 1996-4617

\section{Publisher}

Centre d'étude français sur la Chine contemporaine

\section{Printed version}

Date of publication: 1 March 2016

Number of pages: $5-28$

ISSN: 2070-3449

\section{Electronic reference}

David Zweig, «A Photo Essay of a Failed Reform », China Perspectives [Online], 2016/1 | 2016, Online since 01 March 2016, connection on 28 October 2019. URL : http://journals.openedition.org/ chinaperspectives/6893; DOI : 10.4000/chinaperspectives.6893 


\title{
A Photo Essay of a Failed Reform
}

\author{
Beida, Tiananmen Square and the Defeat of Deng Xiaoping in 1975-76
}

\section{DAVID ZWEIG}

\begin{abstract}
In mid-1975, Deng Xiaoping, with Mao's blessing, initiated reforms that targeted the negative consequences of the Cultural Revolution. To bolster Deng's effort, Mao endowed him with penultimate authority over the Party, government, and military. However, in late October, Mao turned on Deng, and within five months, Mao and the radicals toppled Deng from power. As a foreign student at Peking University, David Zweig observed and photographed four key points in this historic struggle: (1) the initial establishment of a "big character poster" compound at Peking University; (2) emotional mourning for Zhou Enlai in Tiananmen Square following his death: (3) the intensified assault on Deng in February 1976 in the posters at Peking University; and (4) the massive demonstration of support in Tiananmen Square on 3-4 April for the end of Maoist politics.
\end{abstract}

KEYWORDS: Tiananmen Square, wreaths, factionalism, Deng Xiaoping, end of the Cultural Revolution, Peking University, big character poster compound.

\section{Introduction(1)}

$\mathrm{P}$ eople say that Chinese politics is impenetrable. But in 1975-76, politics in Beijing took place on university campuses and in plain view in Tiananmen Square. The launching of a "big character poster compound" (dazibao qu 大字报区) at Peking University (hereafter Beida) in midNovember gave foreign students a front row seat to the polemical attacks authorised by Mao Zedong against Deng Xiaoping and his allies who previously, with Mao's blessing, had mounted a mini-reform movement in summer-fall 1975. Responding to the death of Premier Zhou Enlai on 9 January 1976, some Beijing citizens brought wreaths to Tiananmen Square and publicly expressed deep anguish at the passing of their beloved Zongli 总理 (Prime Minister). By the third week of February, Deng's political days were numbered, but despite Mao's hesitancy to denounce him by name in the posters as the "biggest capitalist roader within the Party" (dangnei zuida de zouzipai 党内最大的走资派), CCP radicals running Tsinghua and Peking universities brightly festooned Deng's name on the posters in an attempt to propel the "Criticise Deng Xiaoping Campaign" (Pi Deng yundong 批邓运动) out of the campuses and a limited number of cities, such as Shanghai and Beijing, and blaze it across the country.

But Zhou Enlai's post- 1972 efforts to improve the economy and undermine the radicals, intensified by Deng in 1975, had found favour in the eyes of Beijingers. So, on 4 April, during the Qingming Festival, a traditional time when Chinese sweep the graves of their beloved departed, as many as two million people visited Tiananmen Square, bringing wreaths and poems, and making speeches in the largest unauthorised protest in Beijing since the anti-Rightist Campaign of 1957. Fearful of a radical victory, they expressed support for the spirit of Zhou and their opposition to the radicals (and perhaps Mao).

The photos presented here portray four "acts" in the political drama running between 20 November 1975 and 5 April 1976. Two sets of photos present the establishment of the big character poster compound at Beida, which I visited regularly at that time, and how the radicals used posters to promote the "Criticise Deng Xiaoping Campaign" in February 1976. A third set shows the mourning that took place on 10 January 1976 in Tiananmen Square following the death of Zhou Enlai, while the final and most dramatic set shows the events in Tiananmen Square on 3-4 April, what is now known as the Tiananmen Incident of 1976, and also as the April Fifth Movement.

For 40 years I used these photos for teaching but never shared them with the world at large. Since I did not want to write a book on the period, I was unsure how to display them. Several months ago, I attached the photo of the mass of people in the square (the photo on the cover of this issue) to a conversation with some colleagues in an online chatroom about current affairs in China, and the response was electric. Everyone wanted me to get them out, particularly as the $40^{\text {th }}$ anniversary of the April Fifth Movement was pending. So I approached Sebastian Veg, then director of the French Centre for Research on Contemporary China (CEFC), with the idea of displaying them in a photo essay in China Perspectives. I chose this outlet for several reasons: CEFC's Hong Kong location allowed us to work face-toface; China Perspectives can produce colour photos, and I wanted to show my shots in their original colour; and finally, as a member of the editorial board, I wanted to support the journal.

I shot the photos with an old but very nice Minolta camera. On the dank, drizzly Saturday before Qingming, I used black and white film, which captured the sombre sense of the square that day. Fortunately I switched to Kodak colour film for the Qingming festival the next day.

These events occurred long ago, and many in the China field know little about this period. I'll therefore begin with some political background to the events and the photos, drawing primarily on my article in The China Quarterly, ${ }^{(2)}$ written when I was a PhD student at the University of Michigan,

This photo essay is published with the support of the project "New Approaches to the Mao Era (1949-1976): Everyday History and Unofficial Memory" funded by the Agence Nationale de la Recherche (ANR; France) and the Research Grants Council (RGC; Hong Kong).

1. I would like to thank Professor Lucien Bianco for his comments on the manuscript, as well as suggestions from Séverine Arsène and Eric Florence. Thanks too to Hugo Petit and Sebastian Veg, who played an important role in bringing this essay to fruition.

2. David S. Zweig, "The Peita Debate on Education and the Fall of Teng Hsiao-p'ing," The China Quarterly, Vol. 73, 1978, pp. 140-159. 
the remarkable work of Fred Tiewes and Warren Sun, (3) the report of Genny and Kam Louie about events in Nanjing, (4) Ann Fenwick's doctoral dissertation, ${ }^{(5)}$ an excellent book by Roderick MacFarquhar and Michael Schoenhals, ${ }^{(6)}$ and an older book by Roger Garside, who also observed first-hand the events of 3 and 4 April, those remarkable days in Tiananmen Square 40 years ago. ${ }^{(7)}$

\section{Background to the events of November 1975 - April 1976}

Following the death of defence Minister Lin Biao in 1971, politics in China moderated significantly, as Zhou Enlai, supported by a host of senior cadres, introduced in 1972 what must be seen as a "Rightist counter-current." New policies challenged the Cultural Revolution and contributed to the conflicts of 1975-76. Universities were reopened, science and technology was reemphasised, and more than three million officials pushed out during the Cultural Revolution were "rehabilitated," including Deng Xiaoping, the highest ranking CCP leader purged by Mao who remained alive. Their return placed great pressure on "revolutionary rebels" who had taken authority at the local level, often through violent attacks on established cadres, and the rebels' efforts to keep power in the face of a counter-attack by rehabilitated cadres triggered factional battles, distracting attention from economically productive work.

Nevertheless, until his death, Mao Zedong engaged in a type of policy schizophrenia; on the one hand, he wanted China to prosper economically, scientifically and culturally, and knew that "stability and unity" (anding tuanjie 安定团结) were imperative to building a strong China; hence, his deep hostility towards factionalism. Yet, he could not jettison his dream for China to balance pro-development policies with the "anti-revisionist" policies he had introduced during the Cultural Revolution and which he believed would save China from the same fate as the Soviet Union. ${ }^{(8)}$ These policies included maintaining "class struggle" as the driving force of all politics and keeping politics, not economics, as the sine qua non of all policy decisions; preventing the education of a new class of bourgeois intellectuals within China's universities; and most important, preventing the re-emergence of an inner core of CCP leaders who would use their authority to become a new ruling class, a bourgeoisie within the Party who would take China back down the path to a capitalist society.

Hence, as the photos show, Mao manipulated the politics of 1975-76. ${ }^{(9)}$ While in the summer of 1975 , he let Deng draft a series of policy proposals, in the fall, he encouraged the criticism of these documents in big character posters at Tsinghua and Beida. When Zhou Enlai died, Mao limited popular mourning, angering society. In February 1976, Mao let Deng be attacked indirectly in the posters, and in April, he approved the use of violence to quell the unrest in Tiananmen Square.

\section{Deng's return to the apogee of power, April 1973 - July 1975}

Mao had always liked Deng, convinced of his administrative skills and political toughness. ${ }^{(10)}$ So, once Zhou Enlai's illness forced Mao to find a successor to the Premier, and essentially to himself, he brought Deng back to Beijing in 1973 and quickly bestowed on him all the trappings of political authority. Deng quickly became Army Chief of Staff, soon thereafter rejoined the Politburo and Military Affairs Commission, and in January 1975 was promoted to Vice-Chairman of the CCP. From July to October 1975, he dominated all policy making within the leadership.

Still, Deng's return complicated leadership politics in China. A deep policy and power chasm separated Deng and his allies from those whom Mao would soon label the "Gang of Four." In 1974, to weaken Zhou Enlai, stop him from rehabilitating more old cadres and block his reform efforts, the latter group launched the "Criticise Lin Biao and Confucius Campaign" (Pi Lin Pi Kong yundong 批林批孔运动), which had a major impact across many sectors of Chinese society. Political tension also existed between Deng's team and the moderate victors of the Cultural Revolution, such as Hua Guofeng, Ji Dengkui, Wu De, Chen Xilian and Chen Yonggui, who had filled the slots of top leaders deposed during the Cultural Revolution. But the primary battle line was among these latter two groups and the radicals, including jiang Qing, Zhang Chunqiao, Yao Wenyuan, Wang Hongwen, ${ }^{(11)}$ Chi Qun and Xie Jingyi (who ran Tsinghua University), and Mao's nephew, Mao Yuanxin, who became Mao's eyes and ears in late 1975. These radicals resisted Deng's reforms and utilised Mao's concerns about Deng to undermine his program.

Second, while Mao supported Deng's efforts to rebuild China's stagnant economy, develop science, and end factionalism at all levels of the political system, the Chairman feared that Deng was not committed to protecting the heritage of the Cultural Revolution. So, as soon as Deng advocated policies that negated core elements of the Cultural Revolution, particularly those related to education, Mao first criticised Deng and then again stripped him of all power.

Still, for three months, from July to October 1975, Mao side-lined the Politburo radicals for incessant factional activities and gave Deng Xiaoping total control of the government, the Party and the army. During this period, Deng and his coterie of veteran cadres promoted a "consolidation" (zhengdun 整顿) program. To develop reform proposals, in early July, Deng established a new State Council Political Research Office, staffed by his lieutenants, including Hu Yaobang, Hu Qiaomu and Deng Liqun, who drafted three reform documents. As Mao requested, Deng and ji Dengkui attacked factionalism across the country, arresting many "revolutionary rebels" who had come to power violently during the Cultural Revolution. Factionalism in Zhejiang Province was a major target in summer 1975. Deng also de-

3. Fred Tiewes and Warren Sun, The End of the Maoist Era: Chinese Politics in the Twilight of the Cultural Revolution, 1972-1976, New York, M. E. Sharpe, 2007.

4. Genny Louie and Kam Louie, "The Role of Nanjing University in the Nanjing Incident," The China Quarterly, Vol. 86, 1981, pp. 332-348.

5. Ann Elizabeth Fenwick, The Gang of Four and the Politics of Opposition: China, 1971-1976, Stanford University, October 1983, received from University Microfilms International, Ann Arbor, Michigan, 1984

6. Roderick MacFarquhar and Michael Schoenhals, Mao's Last Revolution, Cambridge, MA, Belknap Press of Harvard University Press, 2006.

7. Roger Garside, Coming Alive: China after Mao, London, Andre Deutsch Ltd, 1981

8. One of the nine documents in the polemical debate between China and the Soviet Union, which ensued between 1961 and 1964, argued that Khrushchev had allowed a bureaucratic class to reestablish capitalism in the USSR. See Editorial Departments of Renmin Ribao (People's Daily) and Hongqi (Red Flag), On Khrushchev's Phony Communism and its Historical Significance for the World, Beijing, Foreign Languages Press, 1964; also available at www.marxists.org/reference/ archive/mao/works/1964/phnycom.htm (accessed on 14 December 2015).

9. Tiewes and Sun refute all suggestions that Mao was unaware of the decisions in this period and place responsibility for decisions, such as the use of force against the protestors on 5 April, directly in Mao's lap. Fred Tiewes and Warren Sun, The End of the Maoist Era: Chinese Politics in the Twilight of the Cultural Revolution, 1972-1976, op. cit., p. 483.

10. Ezra F. Vogel, Deng Xiaoping and the Transformation of China, Cambridge, MA, Belknap Press of Harvard University Press, 2011.

11. Tiewes and Sun see Wang Hongwen as being much less involved in the factional battles than all these other players. Fred Tiewes and Warren Sun, The End of the Maoist Era: Chinese Politics in the Twilight of the Cultural Revolution, 1972-1976, op. cit., p. 277. 
manded that all officials "take his three policy documents as the key link" (yi san xiang zhishi wei gang 以三项指示为纲) and encouraged the Minister of Education, Zhou Rongxin, to draft a document on educational reform, advocating an end to "open door schooling" (kai men ban xue 开门办学), (whereby college students spent several months a year engaged in practical onsite activities), group rather than individual exams, admission standards that no longer depended largely on recommendations from work units, and a greater focus on academic studies. This document, begun in September, might have been included as a fourth reform document had the "Big Debate on Education" not been launched. (12)

Education policy was highly relevant to the photos presented here and was a highly sensitive policy issue. Education involved ideology and the training of Mao's generation of "revolutionary successors." For the Chairman, privileged college students must not be alienated from the masses and productive labour. Second, by challenging the Cultural Revolution's "new-born socialist things" (xin sheng shiwu 新生事物), many of which were linked to education, Deng revealed to Mao his intention to overturn many policies from that era and reinforced Mao's fear that Deng had never actually changed his world view. Third, ideology and education was Zhang Chunqiao's turf, who was the Vice-Premier holding the education portfolio, (13) so compared to the other arenas Deng wanted to rectify, this one invaded the territory of a leading radical.

Hu Yaobang and Zhao Ziyang faced a similar dilemma during the 1980s reform decade, when they tried to balance "reform and opening" (gaige kaifang 改革开放), with its inherent liberal tendencies in economics and politics, and the "Four Cardinal Principles" (si xiang jiben yuanze 四项基本 原则), which emphasised the CCP's dominance, the Proletarian Dictatorship (state coercion), the Socialist Road (public property), and Marxism-Leninism-Mao Zedong Thought. Hu and Zhao's emphasis on political reform over CCP dictatorship contributed to the ideological incoherence of the 1980s and the incompatible visions of China's future that erupted in Tiananmen Square in 1989. And just as they failed, largely because Deng opposed significant political reform, Deng's earlier effort in 1975 to combine reforms in education, personnel, the economy, and science and technology, all the while preserving the heritage of the Cultural Revolution, was impossible even for the politically astute Deng so long as Mao remained ultimately in charge. Political snipping by the radicals eventually turned Mao against Deng. As these pictures show, in a precursor to 1989, Chinese society, hungry for change, braved the wrath of the Party-state by rallying in support of the reformer(s) at Tiananmen Square in April 1976.

\section{Deng's program under attack, fall 1975}

Deng's position was undermined for various reasons. Essentially he overplayed his hand, trying to revamp national development in a direction counter to the Cultural Revolution. While he thought Mao was on board, it did not take much for Mao to bail out on him. Deng's position was constantly being undermined by Mao's nephew, Mao Yuanxin, who resented Zhou Rongxin's attack on the Chaoyang Educational Model, established by the younger Mao himself in Liaoning Province. Mao Yuanxin admitted that he began to put anti-Deng ideas in his uncle's head in late September and had clearly caught his attention by mid-October. (14)

Also in October, a vice Party secretary of Tsinghua University, Liu Bing, wrote a letter to Mao that challenged the overall direction of education policy as well as Chi Qun, Chairman of Tsinghua's Revolutionary Committee, and Xie Jingji, a vice Party secretary of Tsinghua, and a leading radical to whom Mao was quite close and protective. ${ }^{(15)}$ While Mao Zedong had chosen to ignore Liu's first letter written in July, he decided that this second one was a broadside against the Cultural Revolution.

Mao responded on 3 November when Wu De, Party Secretary of Beijing, presented Mao's critique of Liu Bing's letters at a conference at Tsinghua University chaired by Chi Qun and Xie Jingyi, the targets of Liu's letters. Zhang Chunqiao weighed in as well; five days later he directly criticised Zhou Rongxin's education policies to his face. On 15 and 16 November, at an expanded Politburo meeting at Tsinghua ironically chaired by a silent Deng, Liu Bing was forced to make a self-criticism, while Deng's two lieutenants, Hu Yaobang and Hu Qiaomu, were asked to explain why they had passed the letters to Mao. The uptick of the meeting was the Politburo's decision to turn the attack on Zhou Rongxin into a campaign to oppose what was now called a "wind of Rightist reversal" (youqing fan'an feng 右倾反安 $风)$, which the radicals claimed Deng had begun in the summer under his "consolidation" policy. ${ }^{(16)}$

\section{The big debate on the "revolution in education" brings on the posters}

As chair of the meetings, Chi Qun on 18 and 19 November launched the "Big Debate on the Revolution in Education" (jiaoyu geming da bianlun 教 育革命大辩论) and the struggle against the "wind of Rightist reversal." At this meeting, Mao's nephew, Mao Yuanxin, who as Mao's major conduit to the outside world could claim to speak for the Chairman, made it clear that Mao Zedong saw this "wind of Rightist reversal" as part of the "two-line struggle" whose real target was to overthrow the Cultural Revolution. (17)

Emboldened by this meeting, the radicals turned Tsinghua and Beida into what Fenwick called "activation points," (18) through which they circumvented the Politburo and publicly aired their conflict with Deng Xiaoping and his "consolidation" campaign. Thus on 20 November, a "big character poster" compound was set up at Tsinghua University, ${ }^{(19)}$ with one set up at Peking University the following day. At Beida, the compound was situated in a large square surrounded by four large dormitories, an easy walk to the major dining hall and the shops. (20) Straw mats, wrapped around poles, formed the walls (Photo 1). The only entrance was guarded round the clock by both faculty and students who carried billy clubs to defend against socalled "class enemies" who might disrupt the campaign. Students were organised into "criticism groups" (pipan zu 批判组), who then wrote posters attacking Zhou Rongxin's summer speeches and Deng's "consolidation" effort. My roommate, the class leader of the second year students in the Phi-

12. Ibid., p. 343.

13. Roderick MacFarquhar and Michael Schoenhals, Mao's Last Revolution, op. cit., p. 391.

14. Ibid., pp. 376-377.

15. Ann Elizabeth Fenwick, The Gang of Four and the Politics of Opposition: China, 1971-1976, op. cit., p. 369.

16. Fred Tiewes and Warren Sun, The End of the Maoist Era: Chinese Politics in the Twilight of the Cultural Revolution, 1972-1976, op. cit., pp. 405-406. For the importance of informal policy "winds," see David Zweig, Agrarian Radicalism in China, 1968-1978, Cambridge, MA, Harvard University Press, 1989, pp. 32-49.

17. There had been several so-called "Rightist reversal winds" since the launching of the Cultural Revolution, including spring 1968 and 1972.

18. Ann Elizabeth Fenwick, The Gang of Four and the Politics of Opposition: China, 1971-1976, op. cit., p. 367.

19. Roderick MacFarquhar and Michael Schoenhals, Mao's Last Revolution, op. cit., p. 409.

20. David S. Zweig, "The Peita Debate on Education and the Fall of Teng Hsiao-p'ing," art. cit., p. 143. 


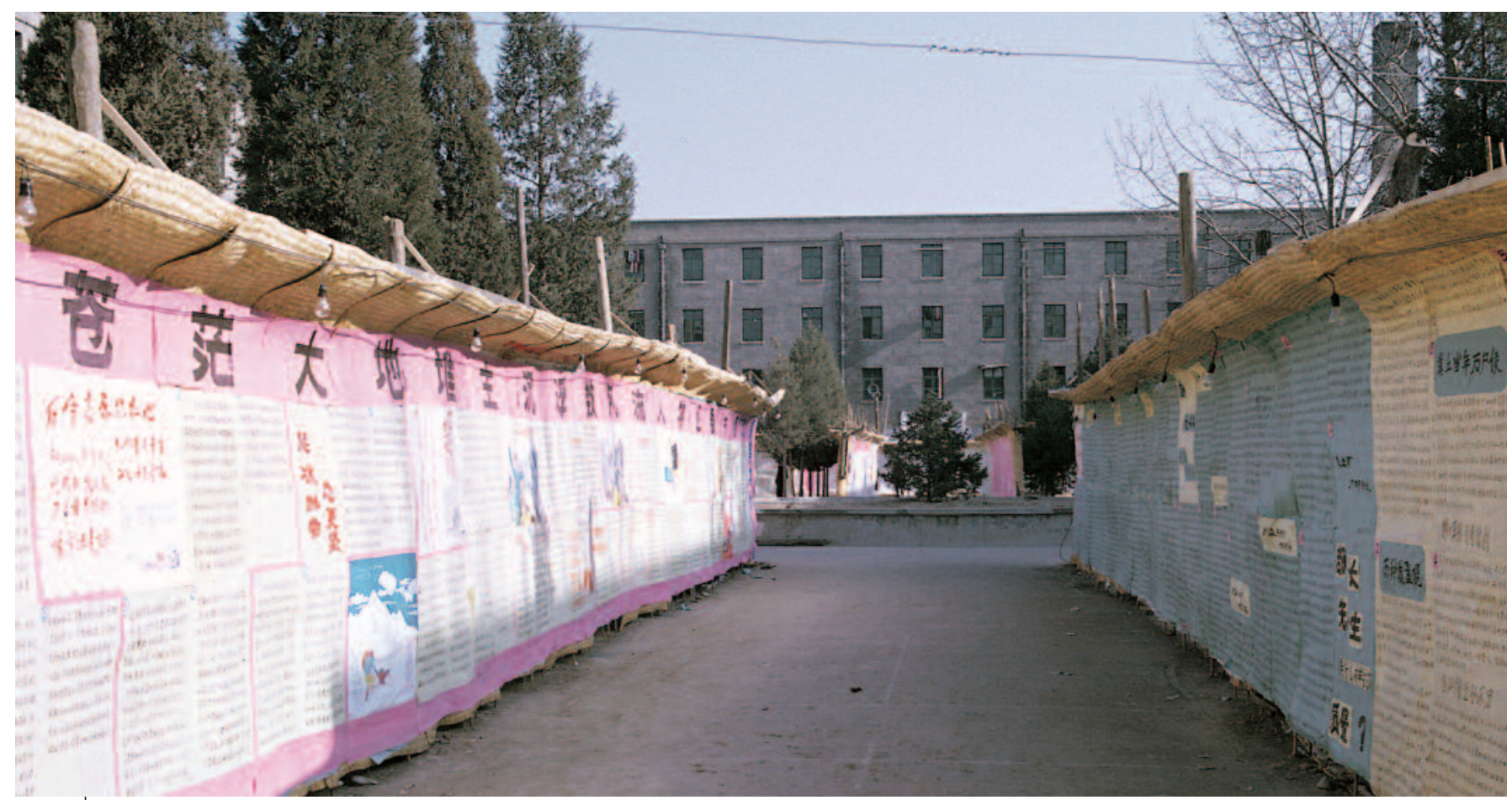

Photo 1 - The character posters courtyard at Peking University. () David Zweig

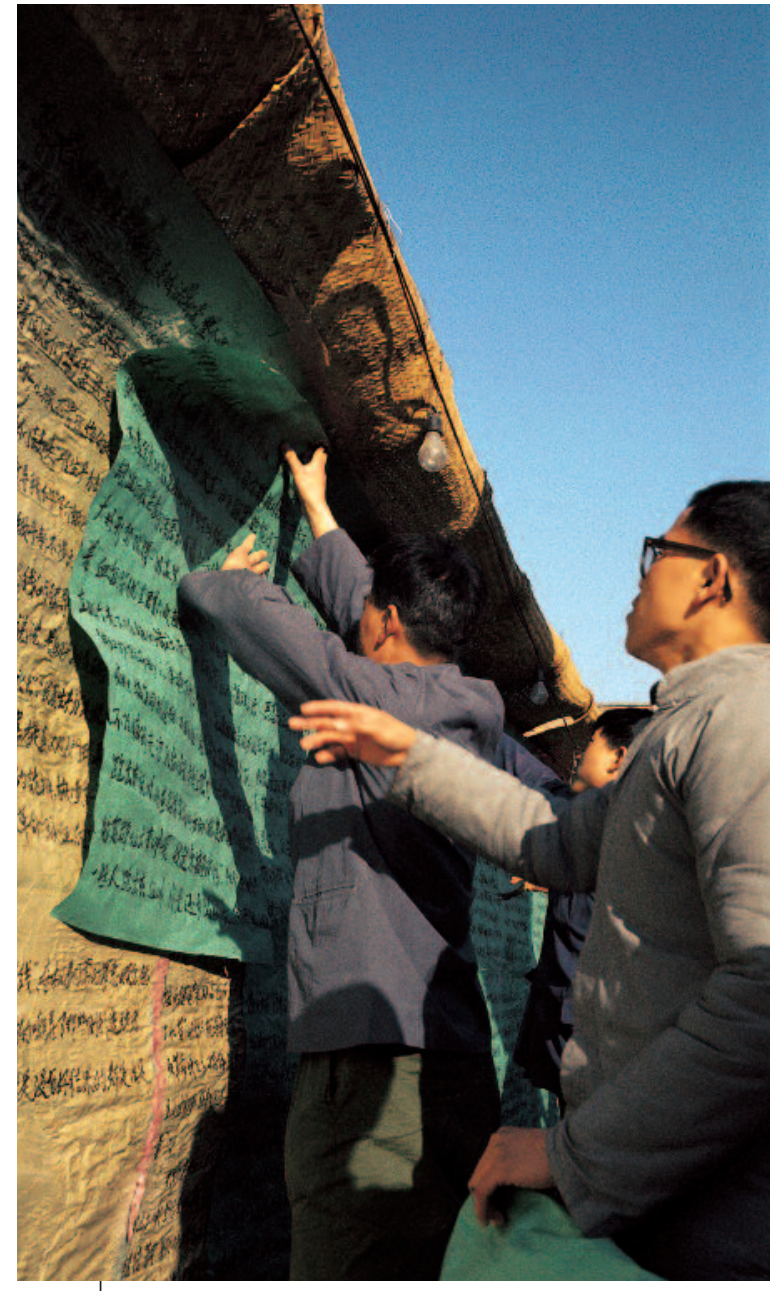

Photo 2 - Pasting up posters at Peking University: November 1975, the early attack. ๑ David Zweig

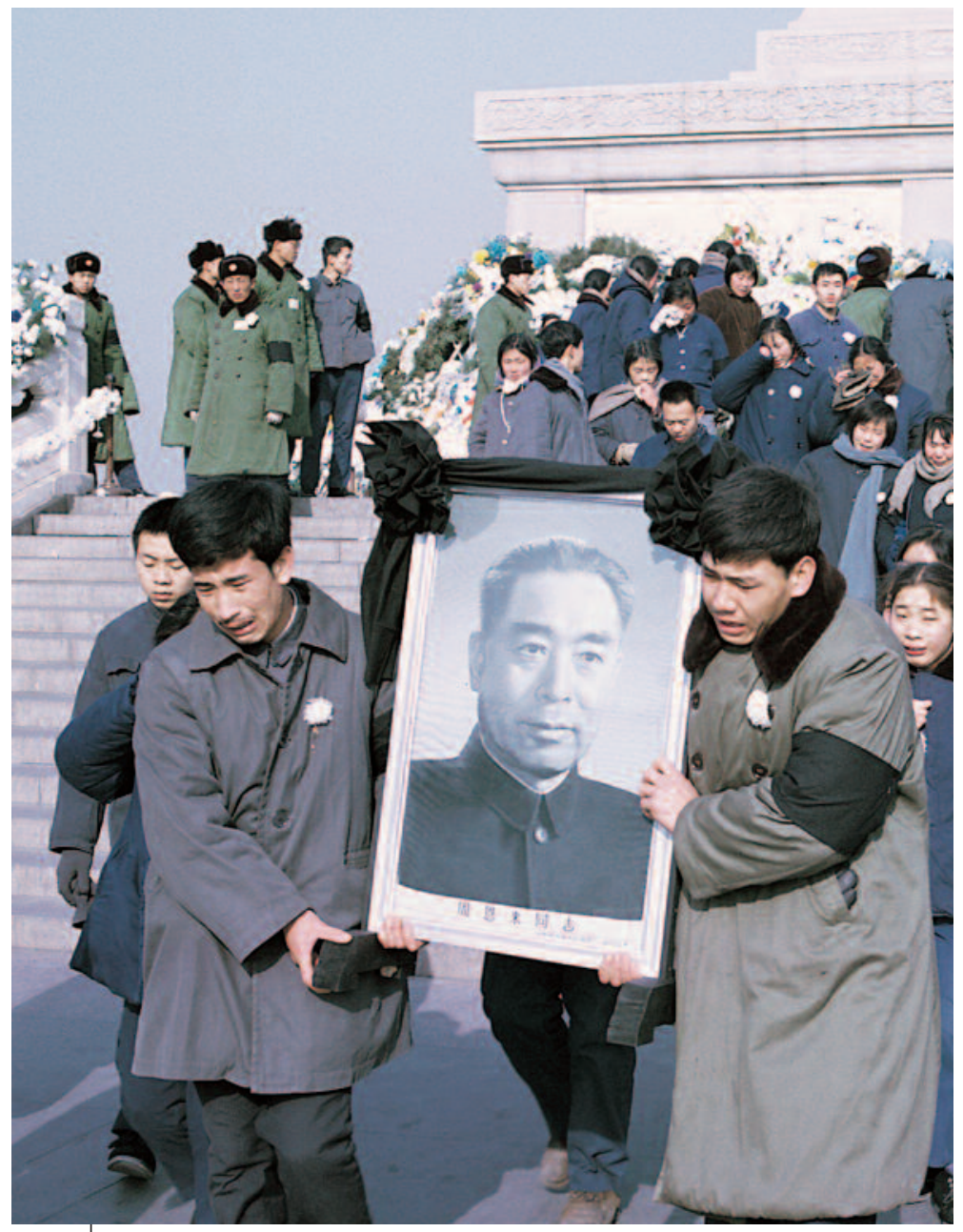

Photo 3 - Zhou's last journey to Tiananmen Square. ๑) David Zweig 


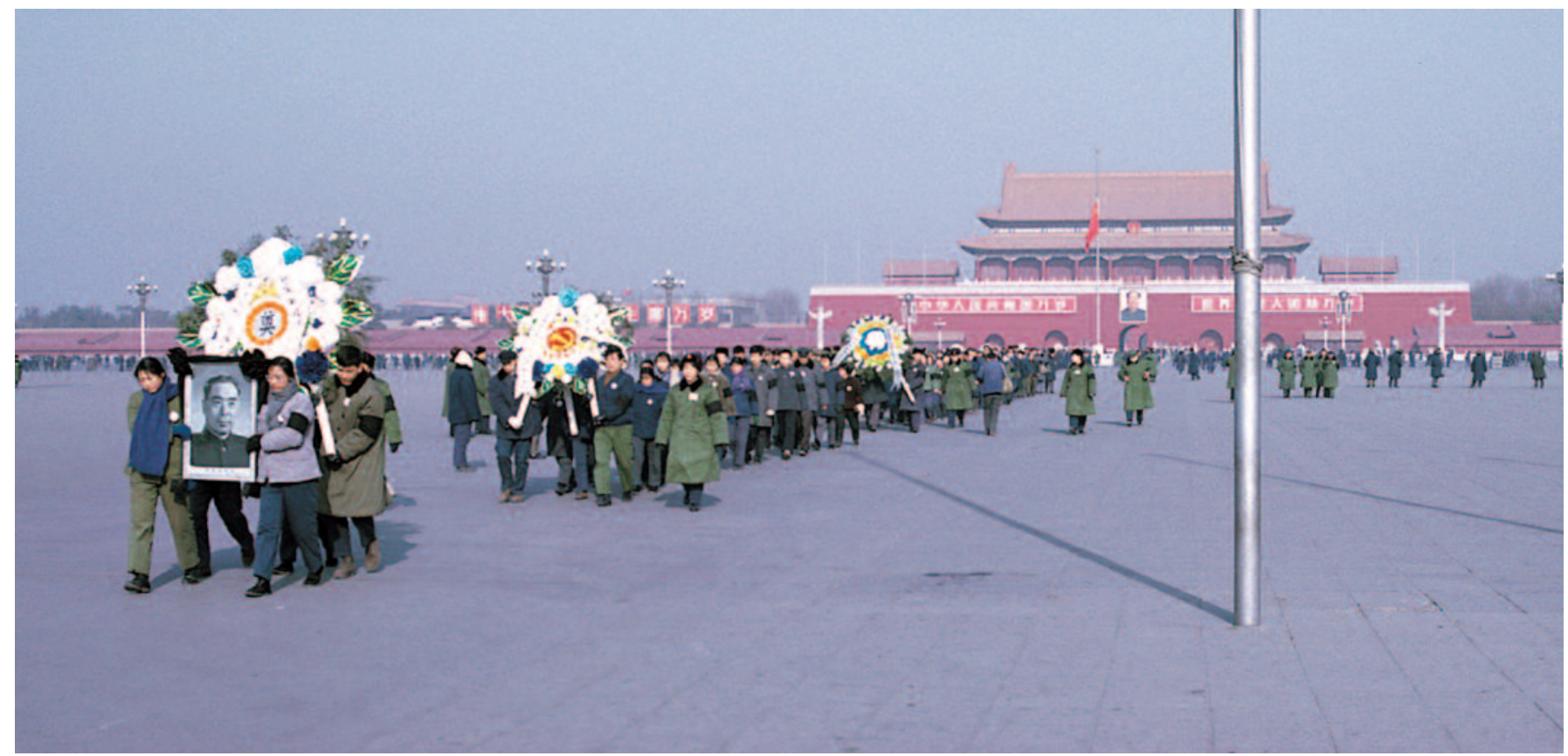

Photo 4 - A trail of mourners in Tiananmen Square: 10 January 1976.

(๑) David Zweig

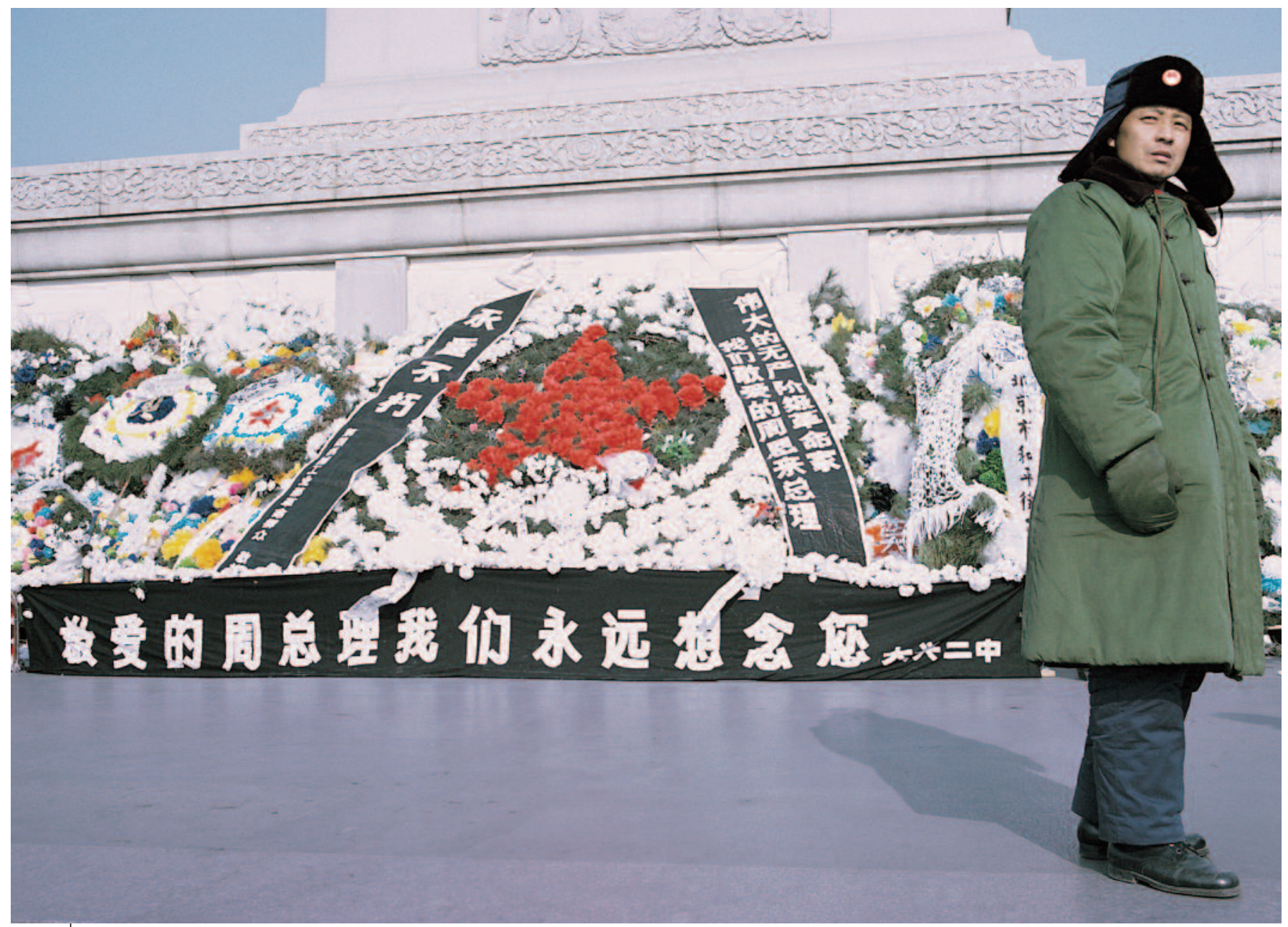

Photo 5 - "Protecting the memory of Zhou Enlai."

(๑) David Zweig 
losophy Department, got his marching orders from the vice Party secretary of the Philosophy Department. Drafts of the posters, once written, were discussed by the criticism groups, and then after they were approved, students with fine calligraphy drew up the posters on multi-coloured paper (Photo 2).The posters included the name of the criticism group, the date they were posted, and a request as to how long they might be left up. In the early days of the campaign, posters rarely lasted more than four days, but as the campaign dragged on, particularly in December, posters began to fray around the edges.

One small poster I read late one night announced that the "Big Debate on Education" had begun after Wu De visited Tsinghua and launched the discussion in the name of Chairman Mao. Zhou Rongxin's summer speeches and various classified policy documents had been passed on to Chi Qun by his allies within the Ministry of Education, which he then passed on to Zhang Chunqiao and Yao Wenyuan. (21) Now excerpts from his speeches and those documents appeared in the posters. Minister Zhou reportedly had said that "the greatest danger in the past four years is not reading books," and had reportedly labelled "open door schooling" as "ultra-Leftist." (22) Early posters at Beida also labelled Liu Bing's letters as "the vanguard of the rightist wind for the reversal of verdicts blowing from all corners of society." (23) To spread the campaign's attack on Zhou Rongxin off-campus, on 27 November a group of outsiders pulled up to the compound in two trucks and a jeep and carefully took notes from the posters. Over the next few weeks, more groups appeared, including foreign journalists, but outside visitors increased most dramatically in February after Deng's name appeared in the posters. ${ }^{(24)}$

\section{Mourning Zhou Enlai in Tiananmen Square, 10 January 1976}

At the crack of dawn on 9 January, while darkness still shrouded the Beida campus, the loudspeaker outside my room began playing a funeral dirge. We quickly learned that China's beloved Premier, Zhou Enlai, had died. Throughout the dorm, the silence of our Chinese roommates was deafening. The next day I bicycled to Tiananmen Square, where I observed long lines of mourners, walking only two or three abreast, and bearing wreaths and photos of Zhou Enlai that they brought to the obelisk situated at the back end of the square (Photo 4). This monument was a meaningful locus for honouring the Premier because while the front, which faces the Gate of Heavenly Peace, is adorned with Mao's massive calligraphy honouring "the people's heroes," the backside, facing south towards Qianmen, bears an epitaph by Mao inscribed with Zhou Enlai's calligraphy. Ironically, the obelisk also bears huge bas-reliefs depicting eight major revolutionary episodes in modern Chinese history. ${ }^{(25)}$

One group I watched, dressed in heavy winter garb, marched across the square, deposited their wreath on the podium, and then withdrew, still bearing Zhou's picture (Photo 3). Despite the limits Mao had placed on the mode of mourning for Zhou, particularly his "five no's" - no black armbands, no wreaths (Photo 5), no mourning halls, no memorial meetings, and no handing out of photos of the Premier - these young people wore armbands and brought wreaths, showing that Mao's hostility to Zhou would not dissuade people from expressing their love for their Premier.

In fact, 30 metres south of the monument, along the tree-lined path to Qianmen Gate, a large crowd stood weeping and lamenting, demonstrating their sorrow to photographers who were catching this historic moment. (26) One young man whose body was shaking as if he were a professional mourner was called forward to make a political statement. The grief of the women seemed to have no bounds, while most men fought back their tears (Photos 6 to 10). Even young children, who could not possibly have understood the event, were overcome by the sadness around them (Photo 11).

While Zhou had played no role in politics after Deng began his "consolidation program," and Deng was already in trouble in October, Zhou Enlai's death heightened the crisis. The "Big Debate on Education" became the "Campaign to Oppose the Right Deviationist Wind." (27) This major escalation benefited the radicals. Mao now had to appoint someone to run the State Council, forcing him to select Hua Guofeng over Deng and Zhang Chunqiao. With this choice, Hua began his ascendancy to the top of the political system. Mao, having declared that "mourning activities are in fact only a cover for restoration" (28) and an attack on the Cultural Revolution, had made his own mistreatment of Zhou into an issue that would come back to bite him in late March and early April, when Chinese around the country used the Qingming Festival to denounce the radicals, and indirectly Mao himself.

In fact, the photographs of 10 January show that while a mass outpouring of grief at Zhou's passing was blocked, sadness and foreboding ran deep. The limited number of wreaths, and the fact that they were not piled very high, suggests that people's actions were tightly controlled. But once Zhou's image came under further attack in late March, the people of Beijing found the right moment to make their political point. (29)

\section{A Chinese New Year tour}

In those days, foreign students were organised for travel within China, and the intense political machinations notwithstanding, our cohort at Beida, under the supervision of the Foreign Student Office (liuxuesheng bangongshi 留学生办公室), took off for Nanjing, Suzhou, Hangzhou, and Shanghai. I looked forward to the trip with great anticipation, seeing it as an opportunity to assess the progress of the campaign against the "Right deviationist wind" outside the capital. In fact, our trip was highly informative and dovetails nicely with the visual story told here. ${ }^{(30)}$

Each city contributed at least one important insight. Unlike Beida and Tsinghua, Nanjing University (Nanjing daxue 南京大学), one of the top schools in China, was politically quiescent - no posters, no meetings, no

21. Ann Elizabeth Fenwick, The Gang of Four and the Politics of Opposition: China, 1971-1976, op. cit., p. 371.

22. This poster, called Zhou Rongxin de fandong yanlun (Zhou Rongxin's Reactionary Statements), was put up by the criticism group of the Geophysics Department, 23 November 1975. Copied by author.

23. Ann Elizabeth Fenwick, The Gang of Four and the Politics of Opposition: China, 1971-1976, op. cit., p. 372.

24. According to MacFarquhar and Schoenhals, 377,000 people would visit the Tsinghua compound over the three months after 22 November. Roderick MacFarquhar and Michael Schoenhals, Mao's Last Revolution, op. cit., p. 410

25. https://en.wikipedia.org/wiki/Monument_to_the_People\%27s_Heroes (accessed on 7 January 2016).

26. That section of trees is now long gone, as it is the location of the Mao Mausoleum.

27. Ann Elizabeth Fenwick, The Gang of Four and the Politics of Opposition: China, 1971-1976, op. cit., p. 378.

28. Fred Tiewes and Warren Sun, The End of the Maoist Era: Chinese Politics in the Twilight of the Cultural Revolution, 1972-1976, op. cit., p. 439

29. In March, I returned to Toronto for my father's funeral with a strong sense that an explosion was pending. I actually drafted an Op-Ed to send to a newspaper, but decided instead that since I was returning to a political hotbed, I was better off not sharing my views with a wider audience.

30. Because I have no pictures from that trip, I only discuss those observations that dovetail with the story here. However, I recommend that those wanting more detail read my China Quarterly article of 1978. 
criticism of Deng's summer 1975 program, and no defence of the "revolution in education." (31) Despite the radicals' exhortation to channel grief over Zhou's passing into the "Campaign against the Right Deviationist Wind," the staff at Nanjing University were following their own tune.

At a Suzhou silk factory, the heads of two pieces of field artillery peeked out of a garage as we walked past. During the subsequent "brief introduction" by factory officials, I asked why there were guns in the factory. The militia, we were told, had been carrying out military activities. This information confirmed visually that Wang Hongwen and the radicals planned to challenge the PLA and Beijing if they came under political attack. Nevertheless, after the radicals were arrested in October, the militia did not act.

The Hangzhou Silk Printing and Dyeing Complex, a key centre in Deng's 1975 battle against factionalism in Zhejiang, ${ }^{(32)}$ had been home to an infamous "revolutionary rebel," Weng Senhe, an ally of Wang Hongwen, who had battled his way into the Provincial Revolutionary Committee before being arrested in summer 1975 for "factionalism." (33) When we arrived, a freshly written big character poster in a back room outlined Weng's factionalist activities. Why a group of foreign students was brought to a factory gripped in political struggle remains unclear, unless pro-Deng forces wanted information about the campaign against factionalism to reach foreign eyes and ears.

Posters displayed weeks later in the Beida compound by university leaders presented the other side of the factional battle. One in particular claimed that in the 20 months since "the old capitalist roader's" return, more than 2,000 "revolutionary rebels" had been removed from office in one ministry alone, while a Beida official in late February told foreign students that in one district outside Beijing, all young radicals had been removed from office. ${ }^{(34)}$

Shanghai, our final stop, showed that the radicals had successfully penetrated the lowest levels of Shanghai's urban society. Blackboards in "hutongs," or narrow thoroughfares, accused unnamed forces of arguing that contemporary China was not as good as before the Cultural Revolution. (35) In a factory we visited, workers had been encouraged to defend the "newborn socialist things," including "worker participation in management" and "management participation in labour." We were also told that in 1972, during Zhou Enlai's "countercurrent" (hui chao 回潮) against the Cultural Revolution, the workers' university had instituted rigorous exams to prove its credentials. But group exams had been reintroduced following the "Big Debate on Education" and the criticism of Zhou Rongxin.

\section{Attacking Deng in the posters, February-March 1976}

In February, the posters intensified the attack on Deng, putting up many expressions that reflected his views, albeit without mentioning him by name. On 10 February, the famous Deng aphorism about the "colour on the cat" appeared in the posters, ${ }^{(36)}$ while another suggested that the campaign's target had declared, "You have thrown me out once; do you think that I am afraid of being thrown out again?"

A key target of criticism was Deng's assertion that Mao had agreed with the idea of "taking the three directives as the key." Mao's support was critical if the documents' policies were to be implemented. But in Mao's eyes, Deng should have persisted in "taking class struggle as the key" (yi jieji douzheng wei gang 以阶级斗争为纲), for to do otherwise would open the doorway for revisionism and the revanche of capitalism. ${ }^{(37)}$ Thus one poster that appeared at this time called for the "absolute unveiling of the counterrevolutionary essence of 'taking the three directives as the key link'" (chedi daichuan "yi sanxiang zhishi wei gang" de fandong shizhi 彻底戴穿 “以三项指示为纲” 的反 动实质). This long poster had been written by the Big Criticism Group of the English Language Department, and drew a great deal of attention from high school students who were brought to the compound to help spread the word (Photo 12).

As February progressed, the radicals tried to expand the campaign outside of Beijing. One day a camera team - a man equipped with a movie camera and a woman who took still shots - descended on the compound. First they went to the top floor of a dormitory overlooking the compound to get a panoramic shot. Then they descended into the compound. Not by serendipity, several busloads of high school students also visited the compound that day, giving it an aura of enthusiasm which no doubt was captured by the photographers. As the poster behind the fellow with the movie camera shows (Photo 13), the radicals by this time were pushing forward the campaign against Deng by displaying posters referring to an "old capitalist roader."

According to Tiewes and Sun, Mao resisted efforts to attack Deng by name, perhaps hoping that Deng would finally see the error of his ways and truly repent. Thus on 25 February, at a month-long "warning meeting" held to inform provincial and regional military officials about Deng's problem and to outline the format for the ensuing campaign, Hua Guofeng forbade criticising Deng by name. In fact, Deng's name was not mentioned in any internal CCP document until 3 March. ${ }^{(38)}$ But the duumvirate of Chi Qun and Xie Jingyi wanted to get on with the "Criticise Deng Xiaoping Campaign" that had been unfolding, and were more willing than the Gang of Four to risk Mao's wrath by naming Deng in the posters before it was authorised. In fact, in early February, Chi Qun was attacking Deng by name in meetings of the Standing Committee of Tsinghua University. (39)

According to rumours in Beijing, on 21 February, as former President Richard Nixon toured the poster compound at Tsinghua University at Mao's suggestion, he asked Chi Qun who was this "unrepentant capitalist roader" - a term reportedly coined by Chi Qun himself. After Chi told Nixon that it was Deng, the cat was out of the bag and Deng's name soon appeared in

31. Nanjing University's president, Kuang Yaming, was the highest ranking official in the province, having been an underground CCP activist before the revolution. He also was quite liberal. While in the late 1970s, leading universities such as Beida and Fudan could not arrange for foreign PhD students to study Chinese society first hand, Nanjing University facilitated numerous theses about rural society, agriculture, textiles, and cottage industries in Jiangsu Province.

32. See "Hangsilian kaichan 'yi xue, si pi, wu da jiang' zuo jiaoyu yundong qingyan" (The Experience of the Hangzhou Silk Complex in Carrying Out the "One Study, Four Criticisms, Five Big Debates" Self-Education Movement), Xuexi wenji (Collected Study Materials), No. 5, 1975, printed by the Zhejiang Provincial People's Publishing House, which reprinted articles from Zhejiang Daily. I bought these study materials on the street, which suggests that they were being widely distributed in the city.

33. Keith Forster, "Spontaneous and Institutional Rebellion in the Cultural Revolution: The Extraordinary Case of Weng Senhe," Australian Journal of Chinese Affairs, No. 27, 1992, pp. 39-75.

34. David S. Zweig, "The Peita Debate on Education and the Fall of Teng Hsiao-p'ing," art. cit., p. 151.

35. A key phrase was jin bu ru xi, or "the present is not as good as the past."

36. The phrase, "bu guan bai mao hei mao, neng zhua laoshu jiu shi hao mao" (It doesn't matter whether the cat is black or white, so long as it can catch the mouse it is a good cat) was a phrase Deng first used in 1962 to support dividing up the collective land to resolve the ongoing famine.

37. Ann Elizabeth Fenwick, The Gang of Four and the Politics of Opposition: China, 1971-1976, op. cit., p. 422. In early January, when the Beida basketball team, of which I was a member, met to "beat back the Right deviationist wind," I had to explain to my team mates why the former view was a "revisionist doctrine."

38. Fred Tiewes and Warren Sun, The End of the Maoist Era: Chinese Politics in the Twilight of the Cultural Revolution, 1972-1976, op. cit., p. 448.

39. Ibid., p. 452. 
A collage of mourners at the back of Tiananmen Square, 10 January 1976

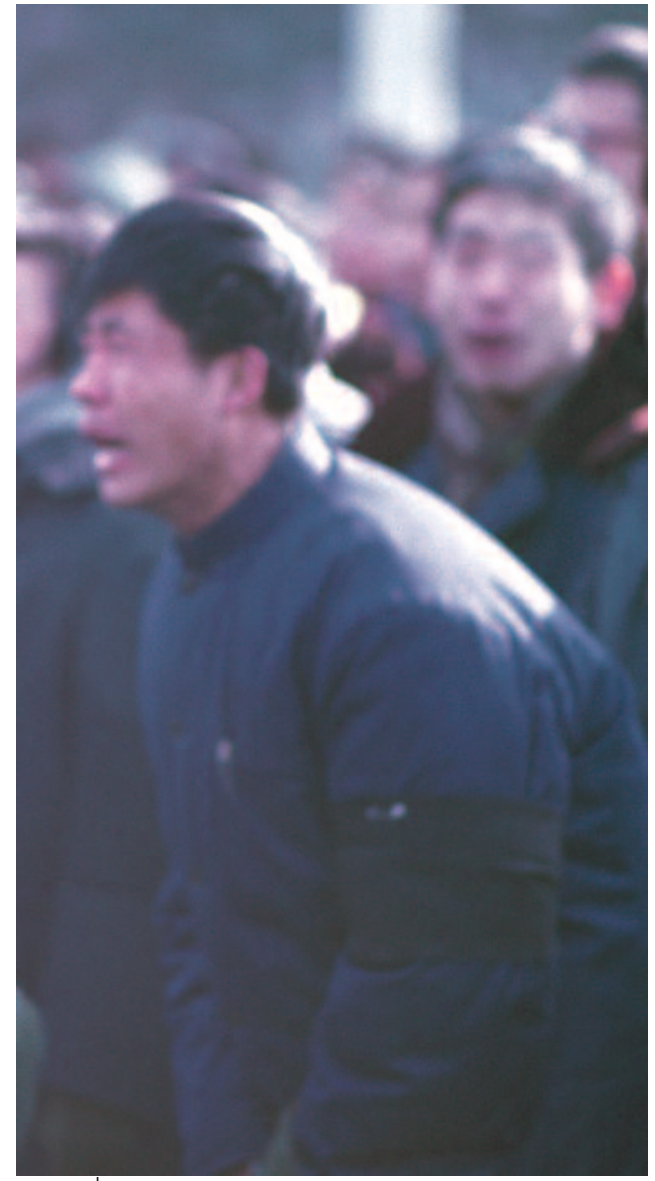

Photo 6 - Shaken to the core

at Zhou's passing. ๑ David Zweig
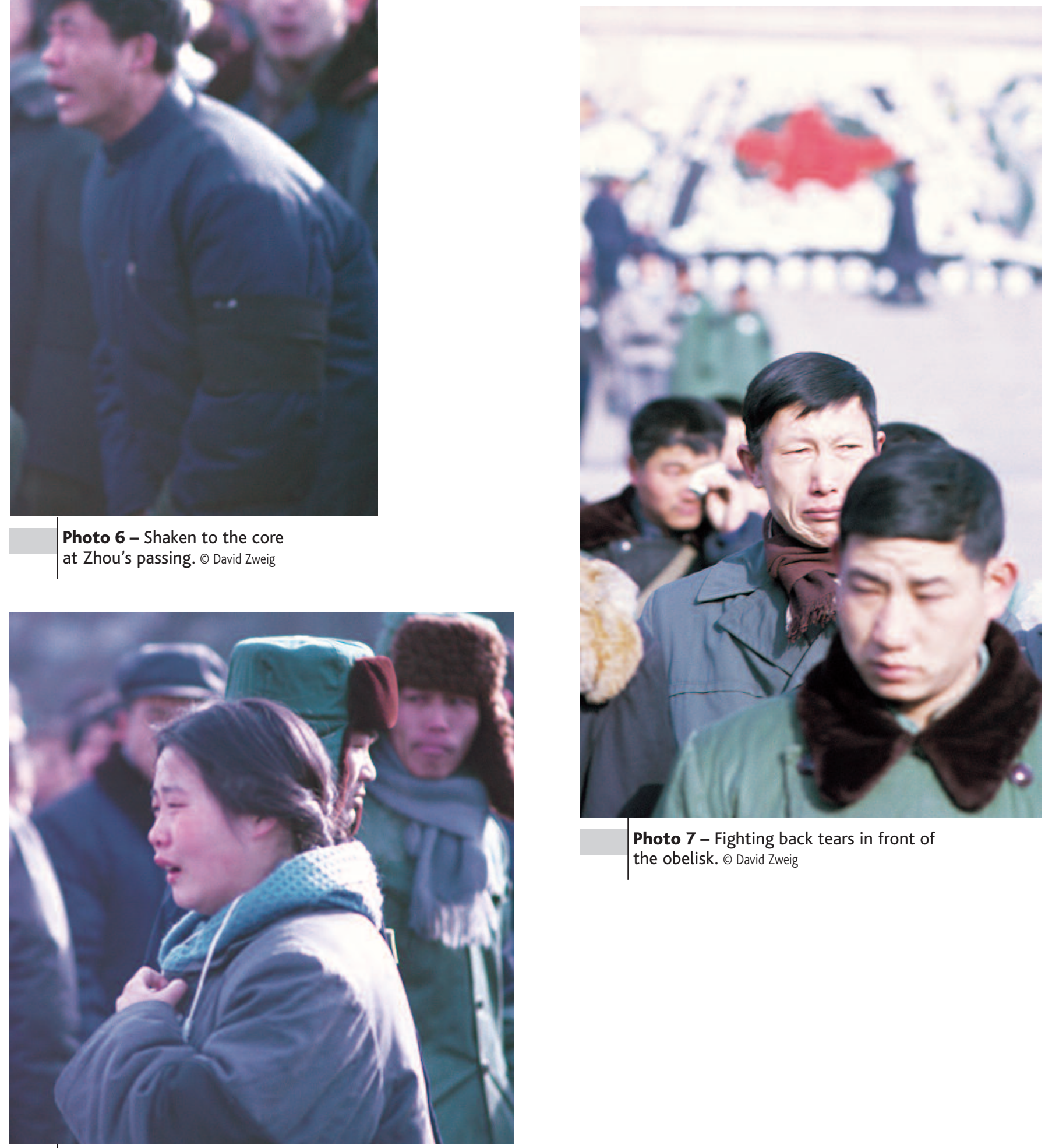

Photo 7 - Fighting back tears in front of the obelisk. @ David Zweig

Photo 8 - A young woman weeps.

๑ David Zweig 


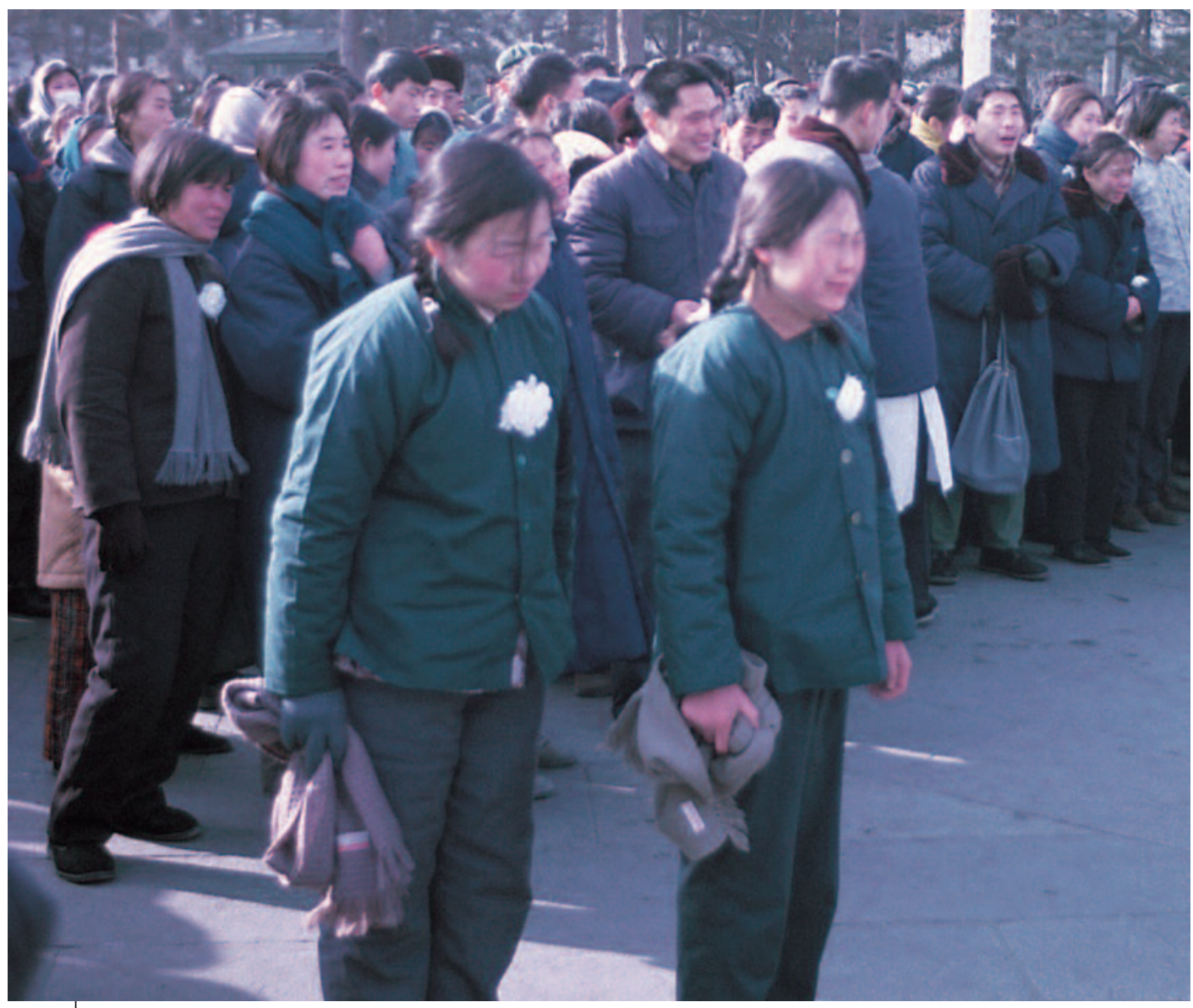

Photo 9 - Sisters in sadness stand out from the crowd. (c) David Zweig

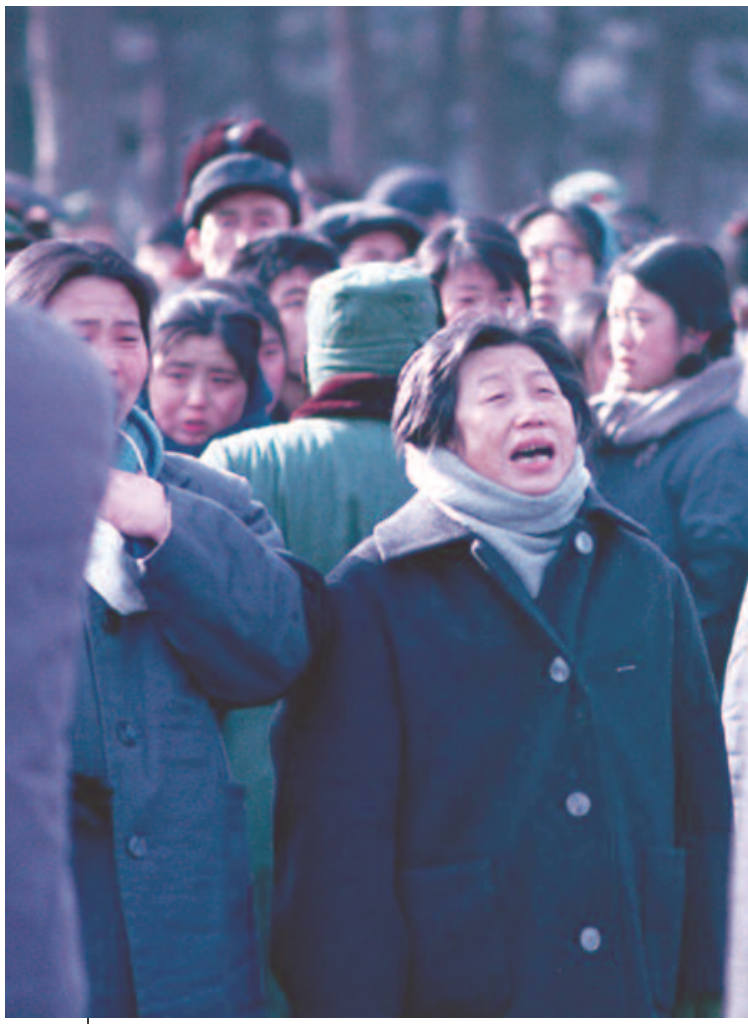

Photo 10 - Like losing one's father. ๑) David Zweig

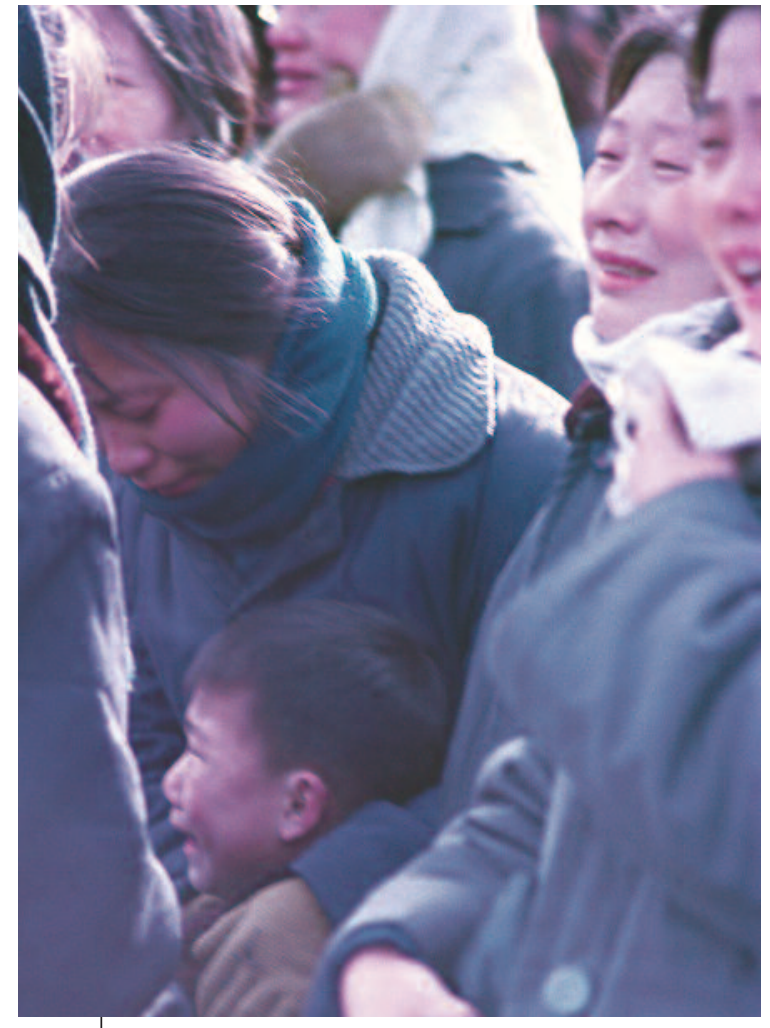

Photo 11 - A young boy and his mother mourn together. @ David Zweig 


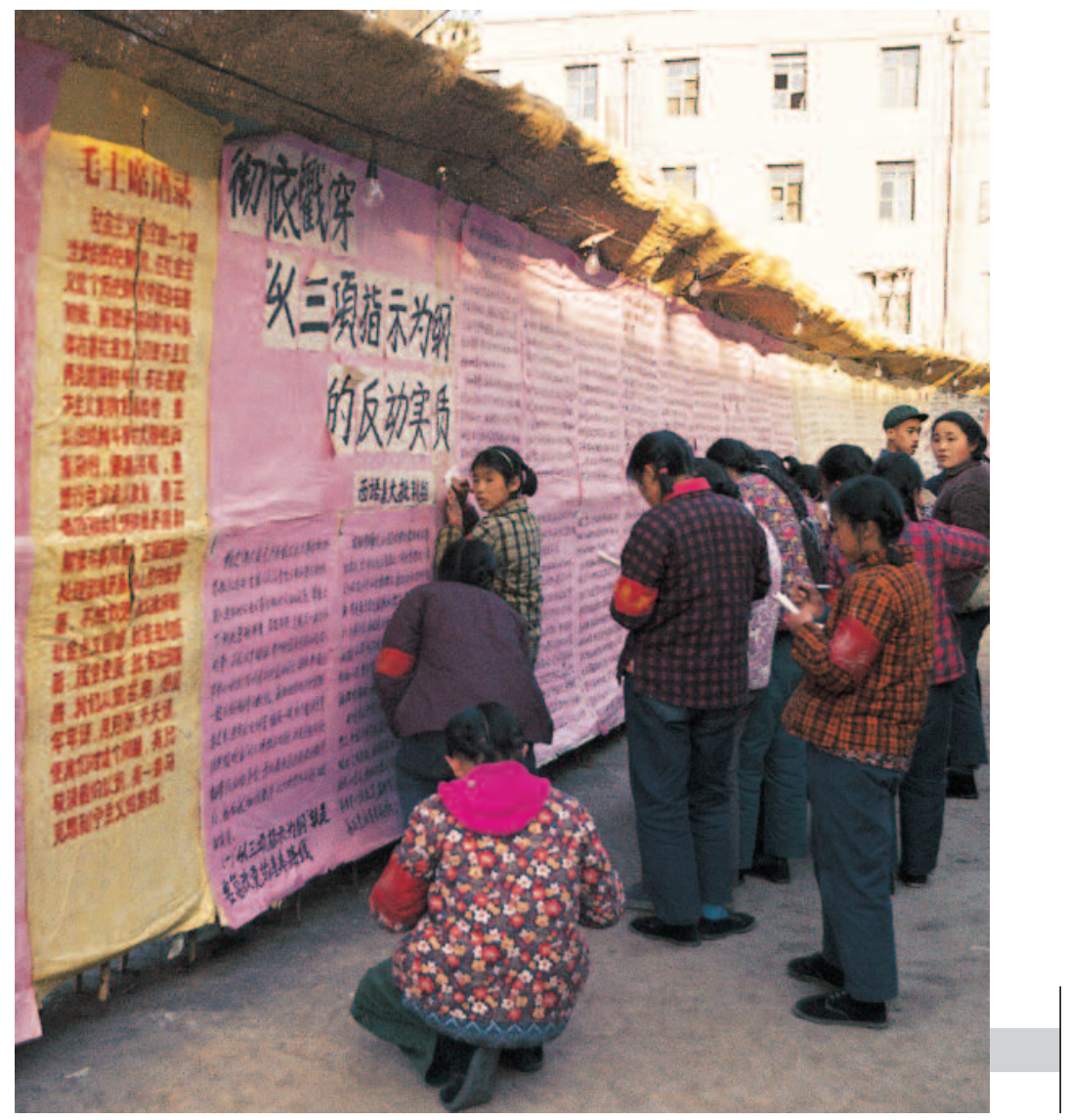

Photo 12 - Deng's "Three Directives" under attack at Peking University, February 1976. ๑ David Zweig

Photo 13 - Trying to extend the Pi Deng campaign outside of Beijing's campuses ๑ David Zweig

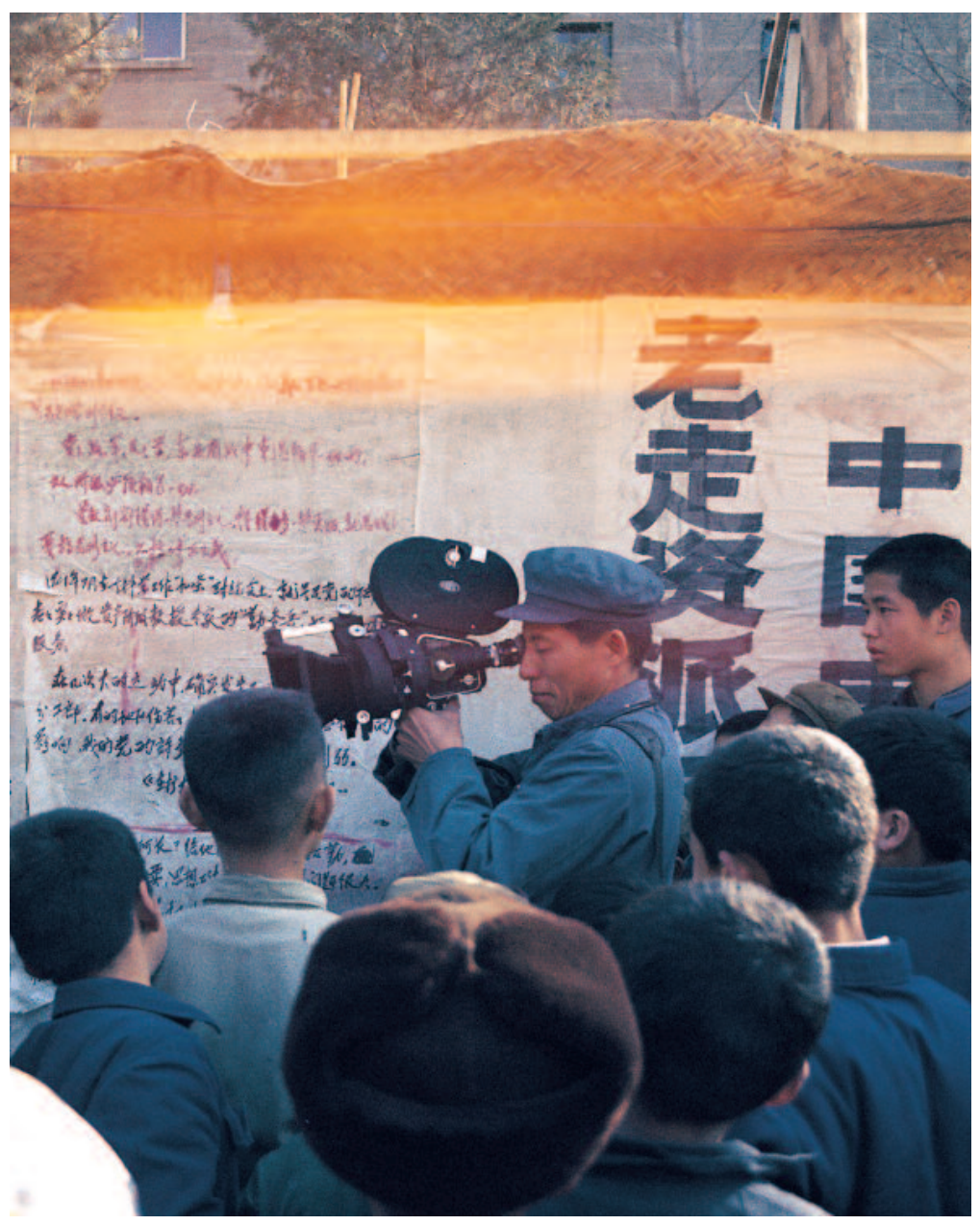




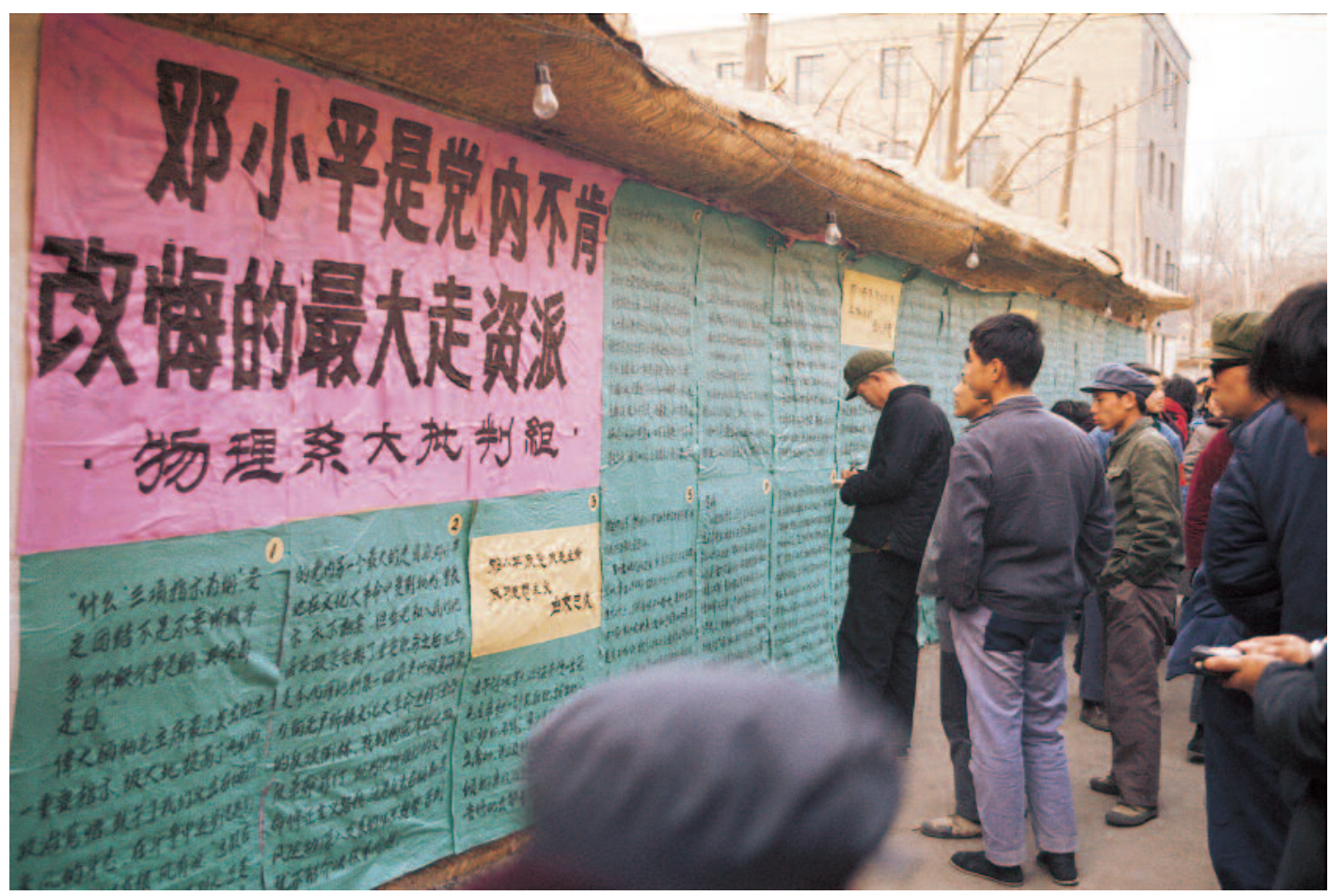

Photo 14 - Deng, that unrepentant "capitalist roader," is on the road again.

(c) David Zweig

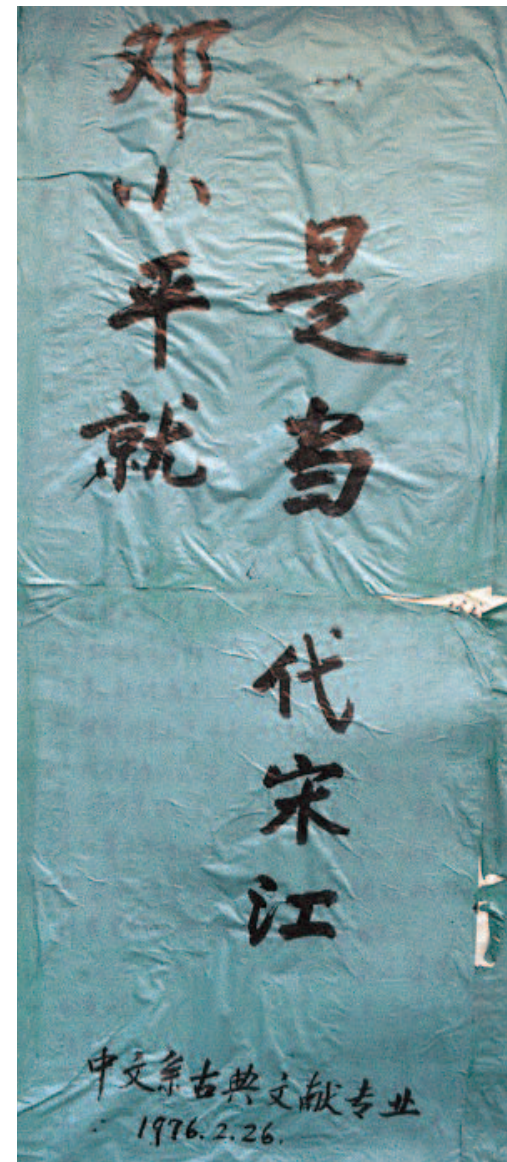

Photo 15 - Capitulating to Capitalism: Deng as a contemporary Song Jiang. @ David Zweig

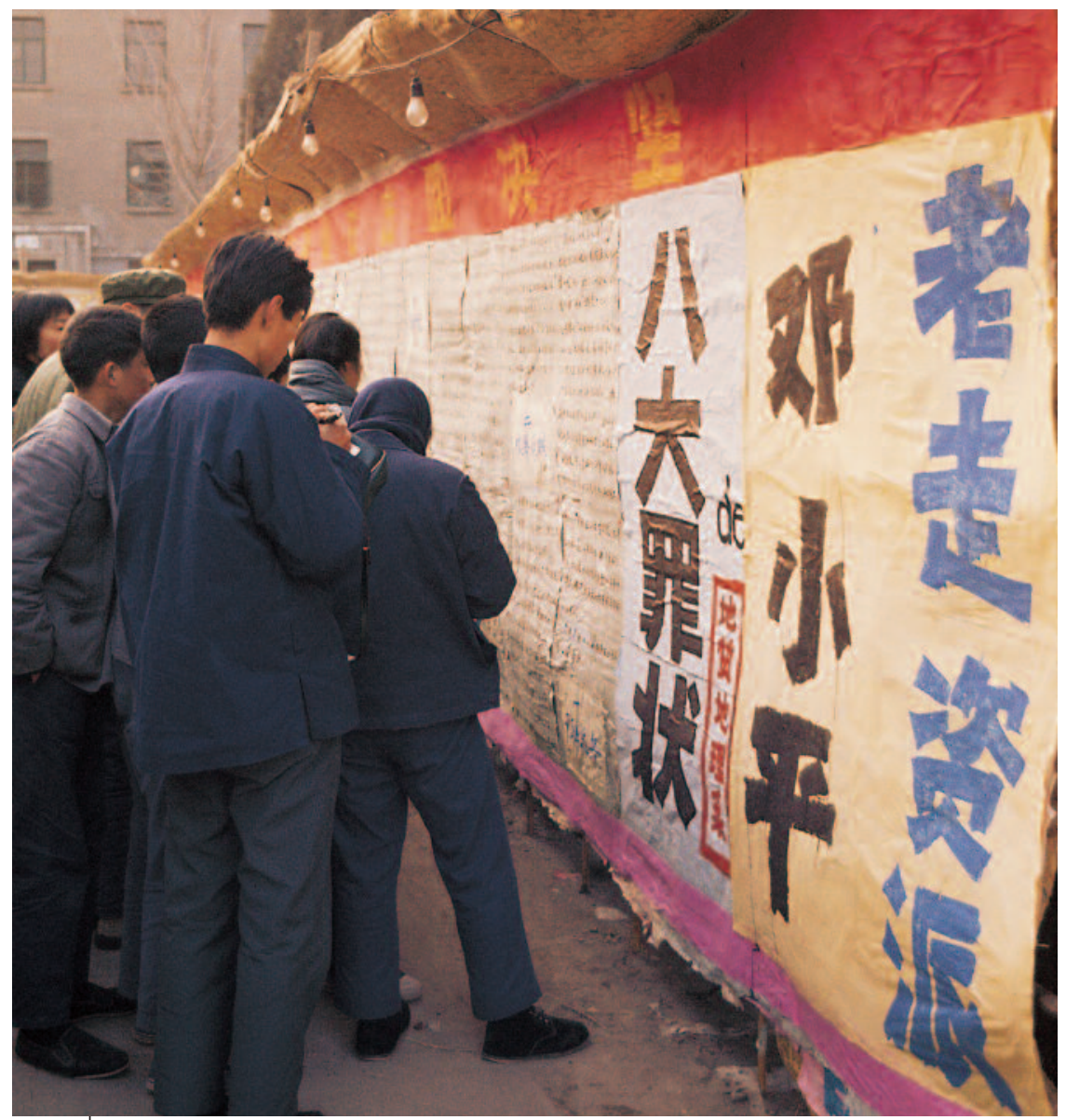

Photo 16 - Deng stands accused at Peking University. ๑ David Zweig 


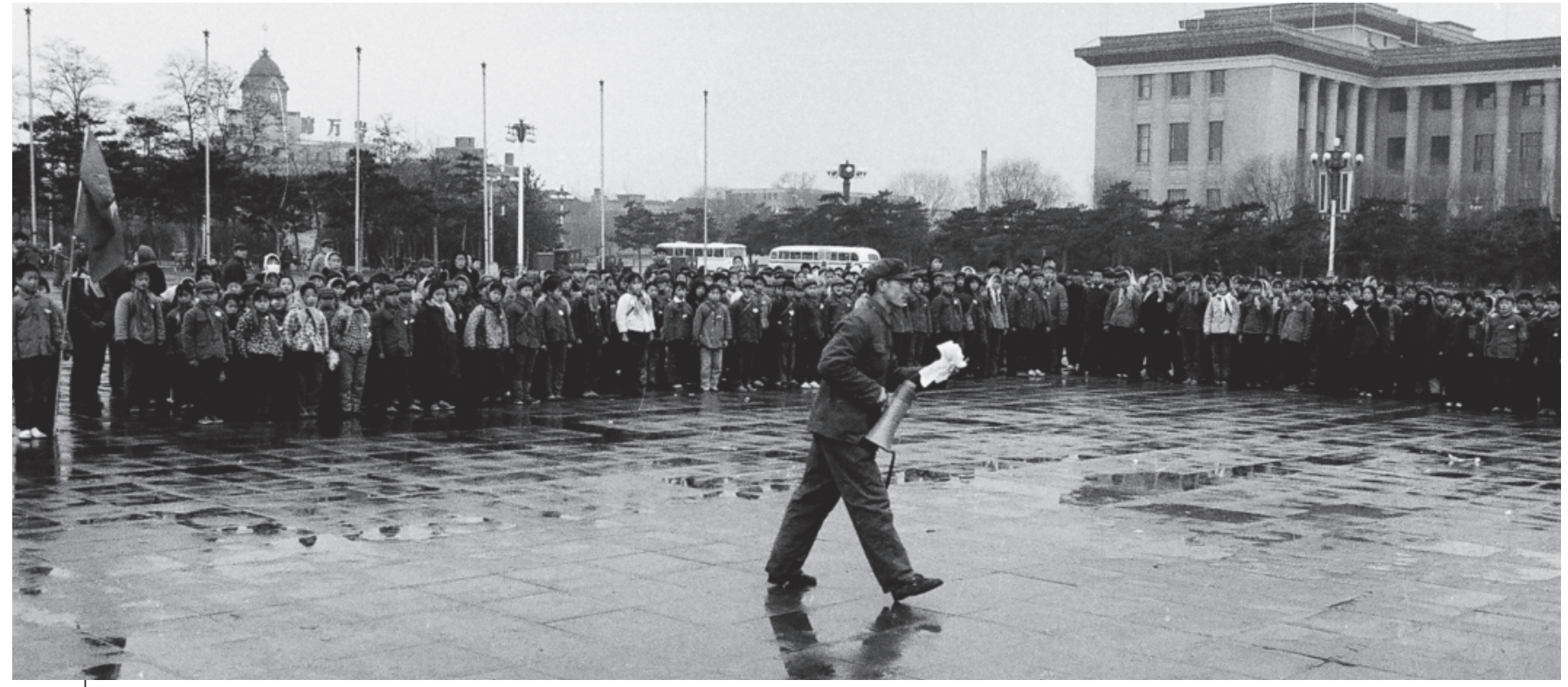

Photo 17 - Organising high schoolers on 3 April.

(c) David Zweig

posters in the compounds, even though there had still been no official approval.

So on 26 February, before the Politburo or Mao authorised it, posters that had previously only referred to an unnamed "capitalist roader" were suddenly emblazoned with strips of paper pasted right across the posters bearing phrases such as "Deng Xiaoping is in fact the unrepentant capitalist roader" (Deng Xiaoping jiu shi dang nei de zui da de zouzipai 邓小平就是党 内的最大的走资派). New posters also declared, "Deng Xiaoping is the biggest unrepentant capitalist roader in the Communist Party" (Photo 14)

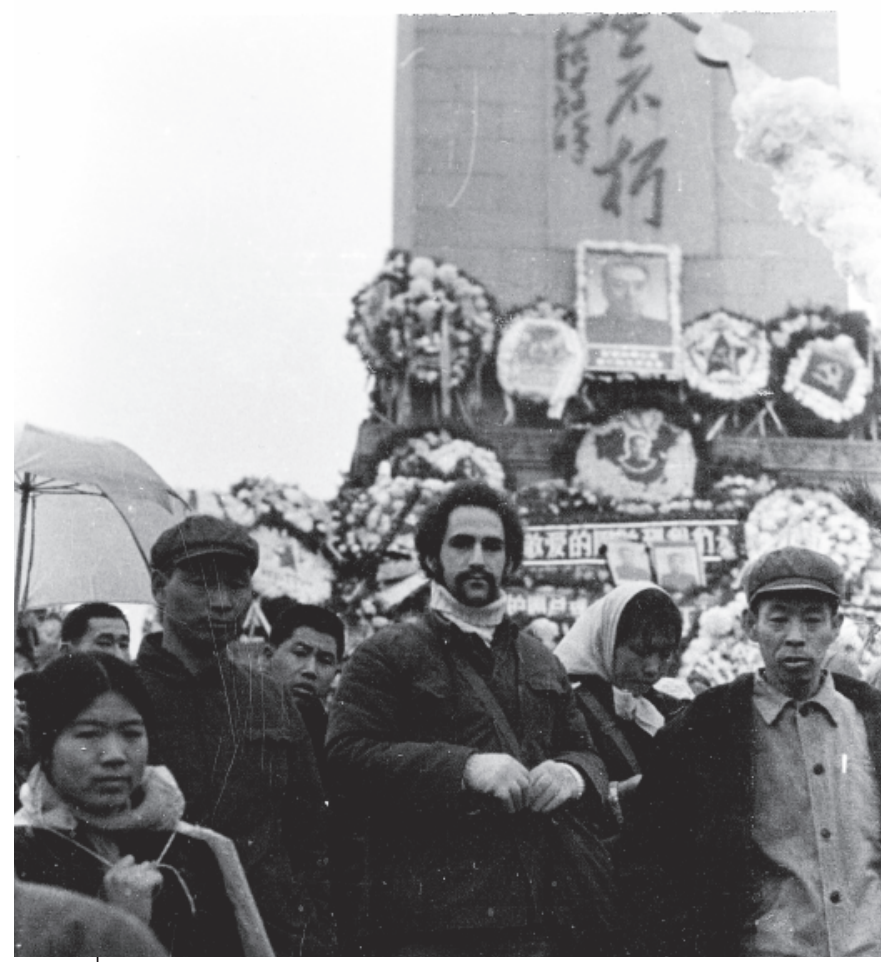

Photo 18 - Standing with Zhou Enlai on 3 April. ๑) Jeremy Paltiel
One posted on 26 February by the "Big Criticism Group of the Literature Department" accused Deng of being a modern day Song Jiang, the hero in the classic Chinese novel, Water Margin, whom Mao had called a "capitulationist" in 1973 and in 1975 (Photo 15). So now the students were comparing Deng to one of Mao's least favourite literary characters. In line with the penchant in Chinese politics to list the "crimes" of leaders under attack - Hu Yaobang would be accused of " 16 great crimes" in 1986, while Zhao Ziyang was charged with "10 great crimes" in 1988 herein Deng faced "eight great accusations" (ba da zuizhuang 八大罪状) (Photo 16).

\section{Towards the April Fifth Movement}

At end of March, Shanghai's leading newspaper, Wen Hui Bao 文汇报, carried a front page article that was widely, if erroneously, interpreted as an accusation that Zhou Enlai was the "capitalist roader within the Party who wanted to help the unrepentant capitalist roader regain power." (40) According to Tiewes and Sun, the Politburo radicals had no intention of attacking Zhou; their target was Deng and supporters he had rehabilitated over the past years. Nevertheless, the idea that the radicals wanted to attack Zhou on the eve of the Qingming Festival mobilised the city of Nanjing, whose students and citizens launched an assault on the Gang of Four and Zhang Chunqiao in particular. Even employees at the Nanjing train station let students paint the sides of trains going to Shanghai and Beijing. ${ }^{(41)}$ These protests spread quickly to 14 provinces and two provincial-level cities. ${ }^{(42)}$ Near the end of March, wreaths began to reappear on the Monument to the People's Heroes in Beijing, the place where citizens had mourned Zhou in January. ${ }^{(43)}$

40. Ibid., p. 468

41. Roger Garside, Coming Alive: China after Mao, op. cit., pp. 111-113, and Genny Louie and Kam Louie, "The Role of Nanjing University in the Nanjing Incident," art. cit., p. 340

42. Roger Garside, Coming Alive: China after Mao, op. cit., pp. 114-115.

43. According to Fred Tiewes and Warren Sun, The End of the Maoist Era: Chinese Politics in the Twilight of the Cultural Revolution, 1972-1976, op. cit., the first wreath appeared on 24 March. 


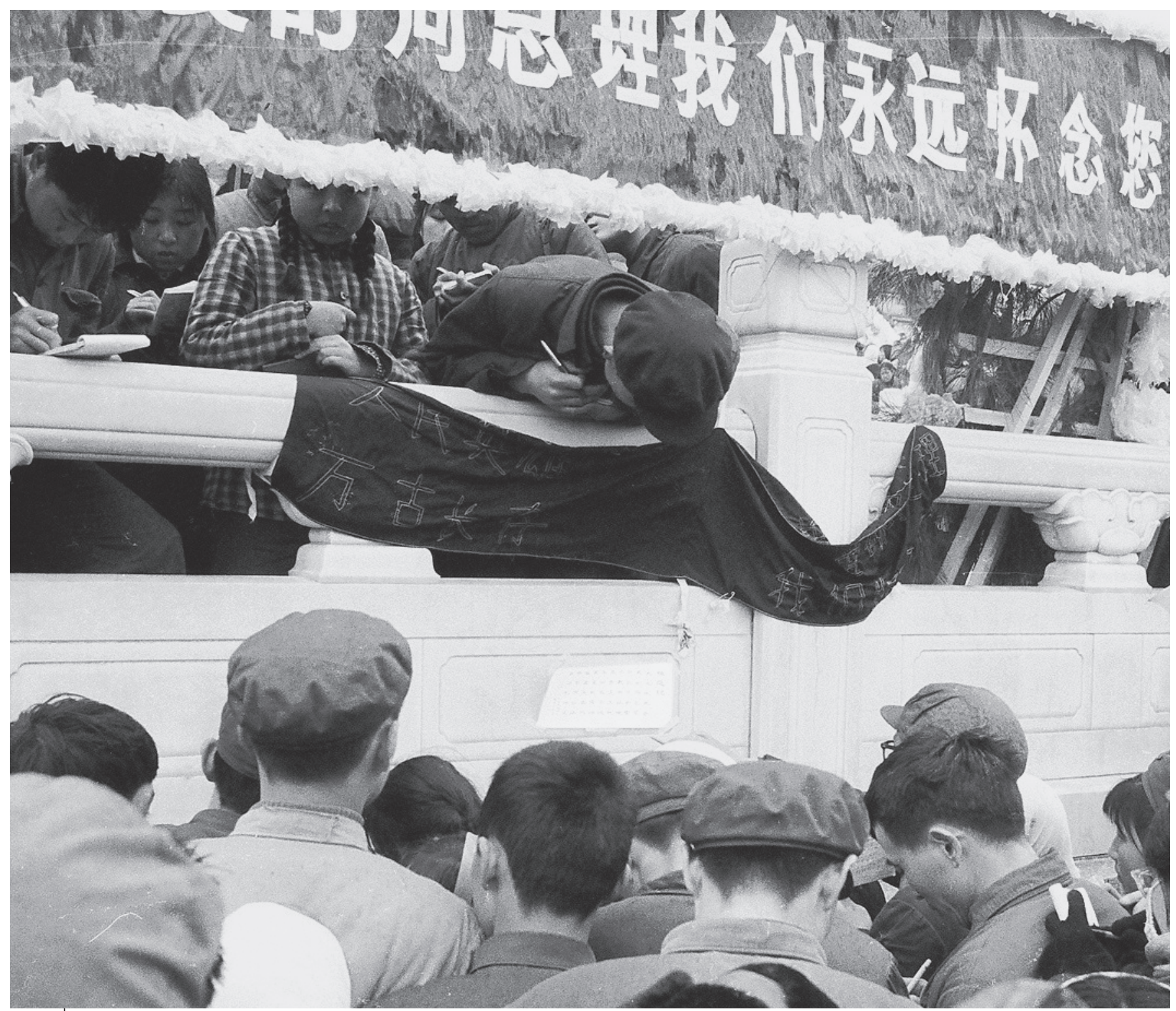

Photo 19 - Small message, big crowd.

(c) David Zweig

\section{A rainy day on Tiananmen Square, 3 April 1976}

My fellow Canadian student, Jeremy Paltiel, and I biked to Tiananmen Square on Saturday, 3 April, the day before Qingming. It was a rainy and eerie day on the square, and the weather matched the mood. Some people were unfriendly to foreigners, unlike the following day when people in the square wanted foreign help to get their views out to the world. A battle seemed underway for control of the square. Jeremy and I saw two people argue below the obelisk when suddenly a man who had been reading the back of a wreath was surrounded by a group that drove him right off the square into the road beside the Great Hall of the People. Still, the wreaths were piled high, though they would go higher on the morrow.

The three black and white photos of the obelisk taken Saturday are from three different angles (Photos 25, 26, and 27). One, from the rear, shows Zhou Enlai's essay, which made the obelisk a good place to mourn his passing (Photo 26). Another, from the side, shows the podium brimming with wreaths
(Photo 27), while a third shows the mass of people that had formed on the north side of the obelisk where the wreaths spilled off the podium on both sides (Photo 25). As another photo taken south of the obelisk, near Qianmen, shows, high school students wearing Young Pioneers armbands, and forcefully organised by a PLA officer (Photo 17), sang songs, marched and saluted.

\section{Tiananmen Square as a transmission channel}

Just as the radicals had used the poster compounds at universities they controlled to air publicly their hostility to Deng's reform program, largely in the hope that it would force the hand of the Politburo and trigger a nationwide campaign, popular resistance to the radicals in late March and early April 1976 used the celebration of the Qingming Festival in Tiananmen Square as their medium for expressing hostility to the radicals and to the future that they (and Mao) had in store for China. Thus many wreaths that were placed in the square had poems critical of the radicals stuck on the back (Photo 28); other short essays and poems were stuck directly on the façade of the obelisk itself (Photo 19). 


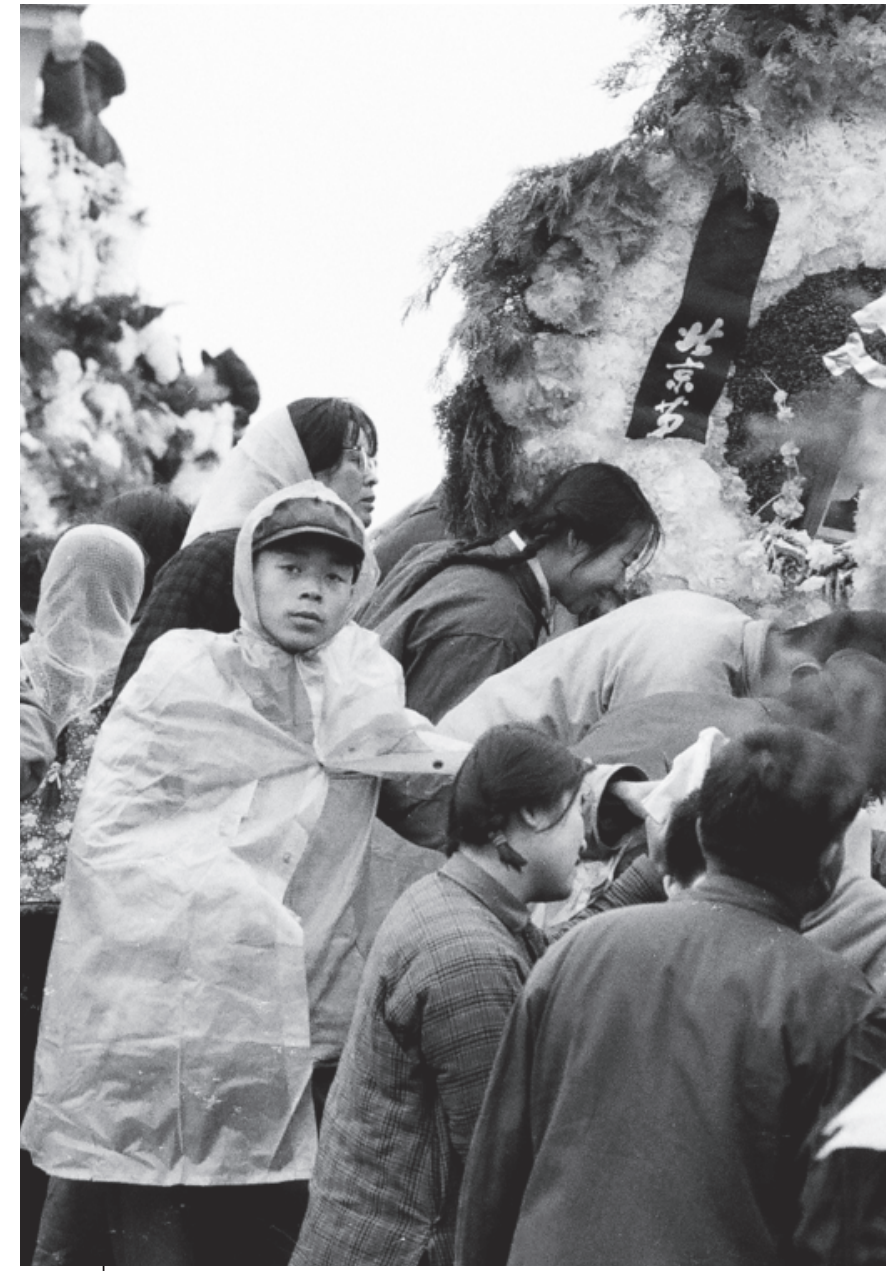

Photo 20 - Rain doesn't stop the readers. (c) David Zweig

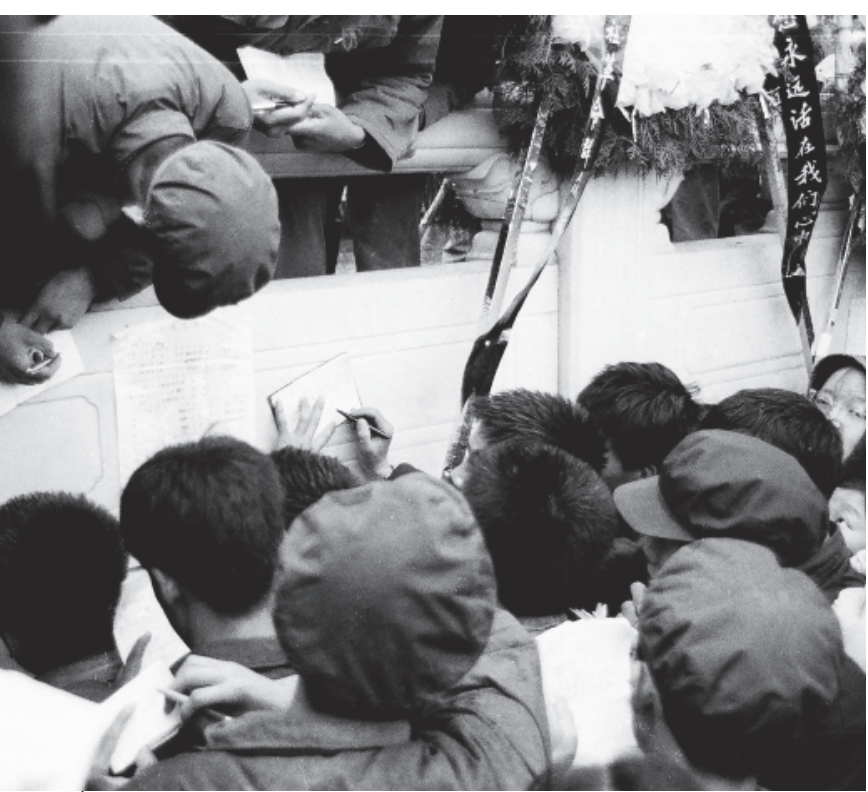

Photo 21 - Coming at the message from above and below. (๑) David Zweig

Thus, as the pictures displayed here show (Photos 20 to 23), despite the rain on Saturday, people went to great efforts to glean information from the poems and mini-essays. Some virtually hung upside down to get access, as

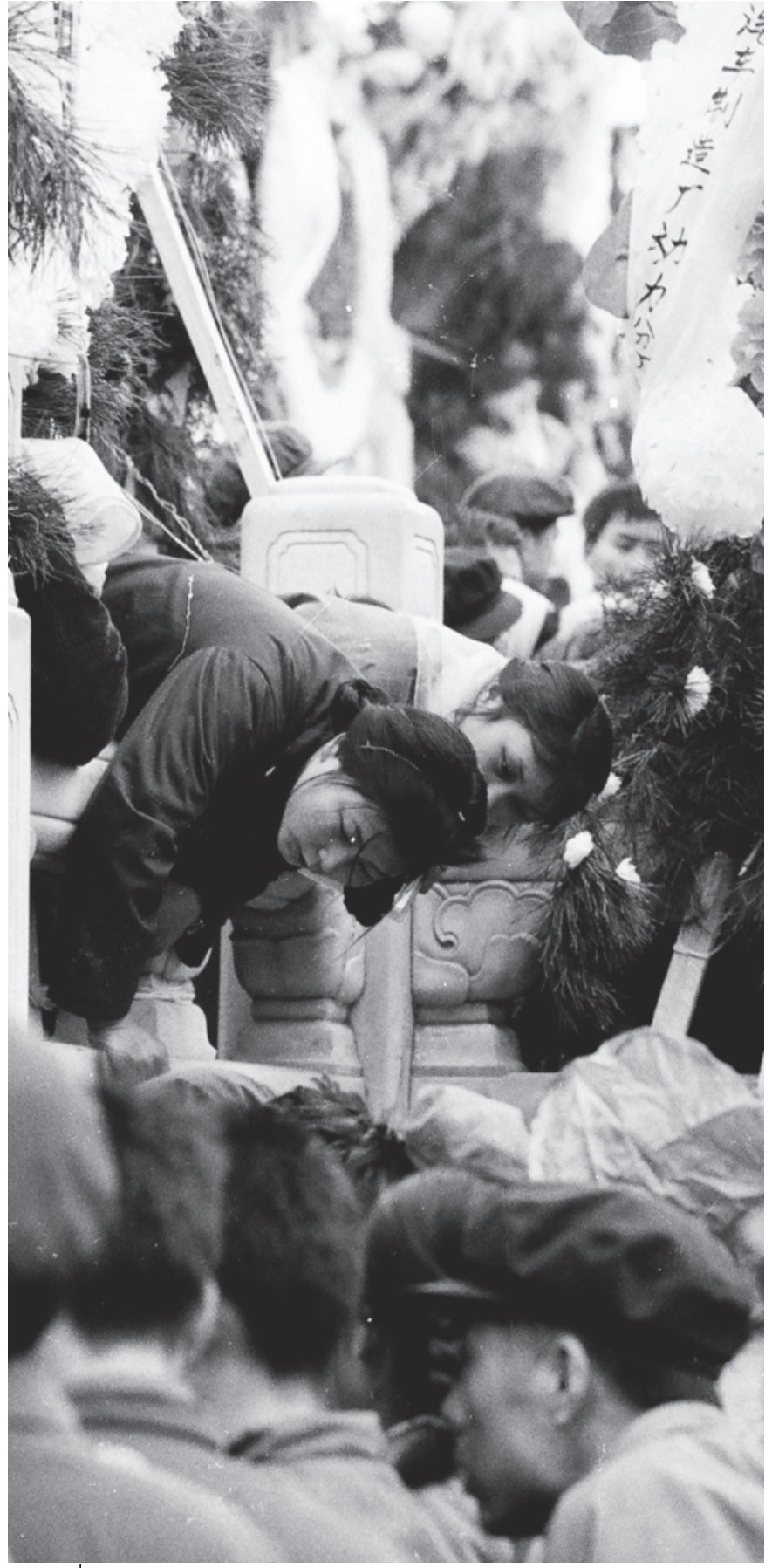

Photo 22 - Hanging in to figure it out. () David Zweig

space in front of the notes was overloaded with people. But whether hanging upside down or standing right-side up or leaning in over people's shoulders, Beijingers scribbled away, becoming nodes or networks between the voices in the square and a Beijing society that hungered to know what others dared to think. The coloured slide from Sunday (Photo 28) shows how these messages drew people to the wreaths, becoming a channel for cryptic critiques of the radicals and of Mao, which Mao and the Politburo radicals, especially jiang Qing, wanted to shut down. Even for some moderate leaders, an attack on Politburo members was an attack on the CCP itself. Thus as one photo shows, a longish text on the side of the obelisk was pasted next to carvings of peasant revolutionaries from China's past, as if facilitating communication between generations of Chinese rebels (Photo 24). 


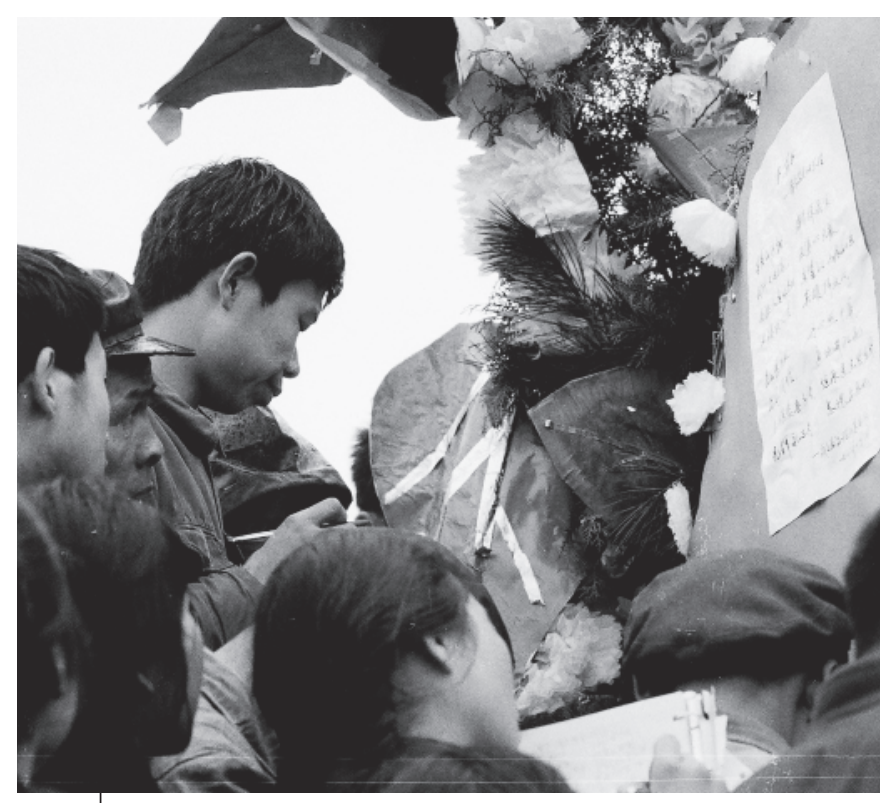

Photo 23 - Making a point others want to share. (c) David Zweig

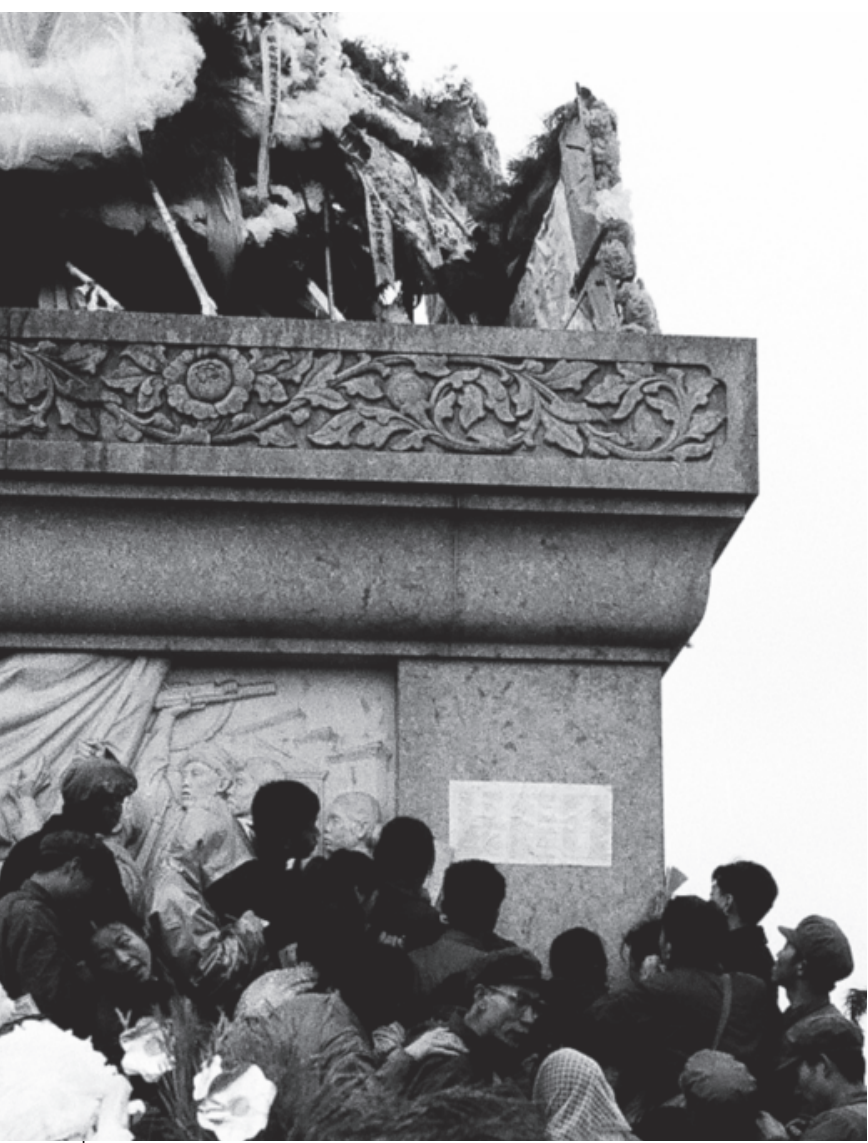

Photo 24 - Speaking to the heroes of the past.

๑) David Zweig

\section{Sunday on the Square, 4 April}

The atmosphere on Sunday morning had changed significantly from the day before. I saw no disagreements, as people appeared united in opposing "Khrushchev-like criminals who sought to usurp power," a reference to
Zhang Chunqiao that was frequently uttered on the square that Sunday. ${ }^{(44)}$ People and wreaths were everywhere, running from the obelisk all the way to Chang'an Avenue (see the cover photo).

Chinese often think that it is dangerous to stand out (or up), as social or political forces will either punish you or drive you back down. But this day, in the northeast section of the square, people rose up continuously from within the crowd, reading prepared texts or making impromptu speeches. One young railroad worker ${ }^{(45)}$ stood above the crowd, expressing support for Zhou Enlai. With his own blood, he had written a "letter of determination" (juexin shu 决心书) to the late Premier on his own t-shirt, which he held up with his bandaged hand for all to see. A man beside him read the text that had been scrawled in blood on his shirt (Photo 30). His persona was magnetic, pulling the assembled mass towards him (Photo 29), and when he raised the t-shirt, the crowd roared with approval. As he prepared to descend, people shouted his name and reached up to touch him. Then everyone sang The Internationale.

People from all social circles appeared on the square that day. According to Yao Wenyuan, one of the radicals, children of high-ranking cadres were deeply involved in that day's events. ${ }^{(46)}$ My photo of a young man wearing a camera around his neck corroborates this point (Photo 31). According to Garside, high-ranking officials had their pictures taken with the wreaths, while Wang Hongwen looked over the square from Tiananmen Gate to assess this challenge to the image of the radicals and Mao. ${ }^{(47)}$ Grandfathers dressed in peasants' garb carried their grandsons on their backs (Photo 32). Children's faces appeared all around the square and up on the obelisk, beautifully framed by the wreaths (Photo 33). One man, dressed in a traditional Chinese jacket, claimed to be a factory worker, though he was probably an engineer. His poem, which was taped by a journalist nearby, was full of gloom (Photo 35):

The sound of mourning stops the earth from turning, and tears have no end.

The dark heaven is crying and beating its own breast.

The earth is also shouting to move heaven.

If tears accompany the sad song, the song will be even sadder. If sadness accompanies the hot tears, the tears will flow still more. Even after the sunset, there will be a dawn,

But after the star has fallen, there will be no light.

The mountains are falling, the world is collapsing,

Grief is like a sea of turbulent tears.

The world is dark and the sky has fallen low.

The north wind blows fiercely and the earth is overturned. (48)

Before stepping down, he shouted: "We will fight back against anyone who attacks our Zongli," and raising his arm, he declared "Long Live Premier

44. Genny Louie and Kam Louie, "The Role of Nanjing University in the Nanjing Incident," op. cit., say that this phrase was widely used in Nanjing as well. Roger Garside, Coming Alive: China after Mao, op. cit., has eight entries for "Khrushchev-like careerists" in his Index.

45. Garside seems to refer to the same young man with the bandaged hand whose picture appears here. Roger Garside, Coming Alive: China after Mao, op. cit., p. 124.

46. Fred Tiewes and Warren Sun, The End of the Maoist Era: Chinese Politics in the Twilight of the Cultural Revolution, 1972-1976, op. cit., p. 474.

47. Roger Garside, Coming Alive: China after Mao, op. cit., p. 125, and Fred Tiewes and Warren Sun, The End of the Maoist Era: Chinese Politics in the Twilight of the Cultural Revolution, 1972-1976, op. cit,. p. 479, respectively.

48. David S. Zweig, "The Peita Debate on Education and the Fall of Teng Hsiao-p'ing," art. cit., p. 155. 


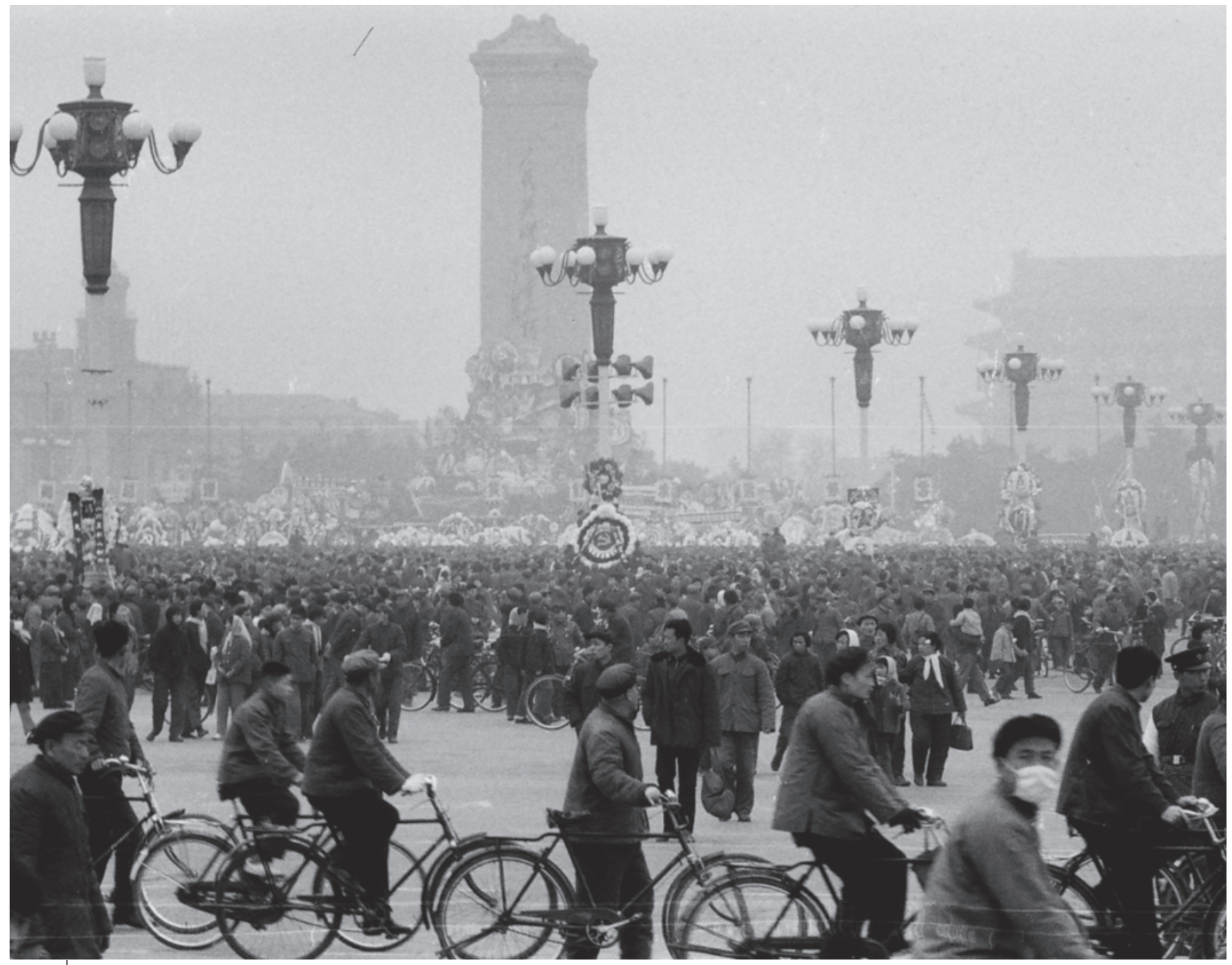

Photo 25 - The wreaths rise high on the obelisk on 3 April: A view from Chang'an Avenue.

(c) David Zweig

Zhou!" Many arms shot up around him as a chorus exclaimed "Long Live Premier Zhou!" Another verse of The Internationale followed. One artist, who set up his easel at the far north of the square, right below Tiananmen Gate, painted the amazing crowd and drew the attention of another man who watched him work (Photo 36).

At one point, a well-dressed woman put a vase with some flowers on of the columns at the north end of the square (Photo 37). The couplet running down the vase's sides announced that the flowers had been sent by the "Revolutionary Professors of Peking University," which generated much excitement, as it suggested that even faculty in that hotbed of "Leftism" dissented from the radical agenda. My camera shutter caught her as she moved quickly through the crowd, almost as if she had planted a bomb and wanted to get away from it before it blew up.

One group missing from the square, and therefore from my photos, was the security forces. Undoubtedly, the square must have been crawling with plain-clothed police, but there was no presence of uniformed police. Still, lots of people stood on wagons and on the carved marble posts just below Tiananmen Gate, taking photographs (Photo 34), while others walked around with cameras.
One poem I copied down greatly frightened my roommate when I read it to him that night back in our dorm. Apparently, a big debate had ensued about whether to build Zhou a mausoleum, and while Mao had opposed that idea, the popular view among the citizenry was that the Politburo radicals were the primary opponents of such a memorial hall, a message clearly articulated in the following poem:

The ashes are not yet cold

Song oppresses the sounds of sadness.

There is an empty seat on the stage.

All the people look towards Qing Ming

But at Qing Ming there is no grave to sweep.

Annoyingly they look to the empty sky

The ashes have been spread across the country's soil. (49)

We hope that the gentleman's clear spirit

Will become an insecticide

To destroy all mosquitos and flies. (50)

49. Zhou's ashes were spread across the country and in the Taiwan Straits.

50. This poem first appeared in David S. Zweig, "The Peita Debate on Education and the Fall of Teng Hsiao-p'ing," art. cit., p. 157 


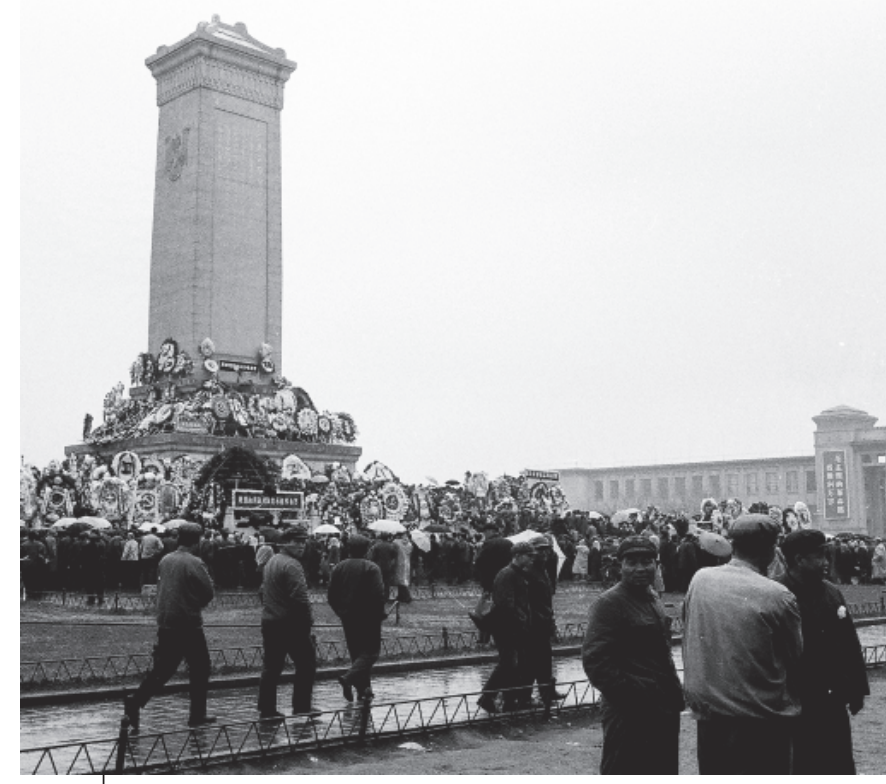

Photo 26 - Zhou Enlai's writing on the back of the obelisk. (๑) David Zweig

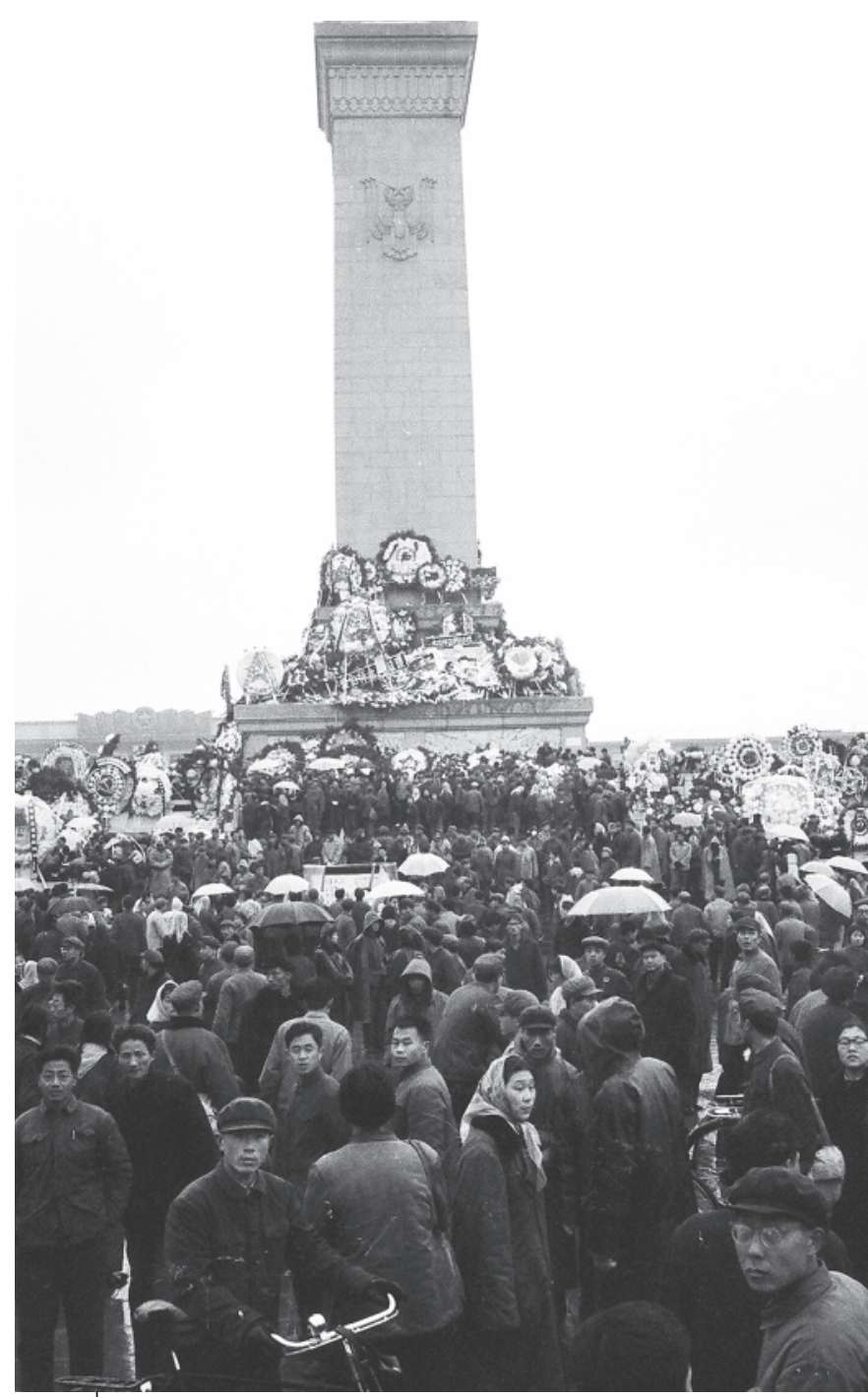

Photo 27 - A side view of the obelisk on 3 April. ๑) David Zweig

\section{The denouement to 4 April}

In the early morning of 5 April, at jiang Qing's insistence, ${ }^{(51)}$ and without Mao's input, the wreaths were removed and some people were arrested for resisting the army's effort to clean up the square. On that same day, Mao authorised the use of force. But although tens of thousands of furious Beijingers poured back into the square after word emerged that city officials had confiscated all the wreaths, and engaged in riotous behaviour such as overturning a police van and setting fire to a command post on the square, ${ }^{(52)}$ the People's Militia hesitated to act, attacking people only after 10:30 pm and for only 10 to 15 minutes. ${ }^{(53)}$ The limited force notwithstanding, the memory of state and CCP violence against the people was irrevocably etched in the PRC's history.

On Wednesday, 7 April, the Politburo unanimously approved a proposal by Mao that Hua Guofeng be made first Vice-Chairman of the CCP and keep his post as Premier. Deng, on the other hand, was stripped of all his posts and blamed for fomenting a counterrevolutionary event. But as they did not revoke his Party membership, he would have the chance for his last and most influential comeback a little more than one year later.

\section{Conclusion}

I often ask my students, "What single event best explains the success of Deng's post-1978 reforms?" They are always puzzled. But the events of this tumultuous period, from the convening of the National People's Congress in January 1975 until the death of Mao on 9 September 1976, demonstrate that Deng's post-1978 reforms would have failed were Mao still alive. Thus, the answer to the question is: the death of Mao.

Yet the events in Tiananmen Square on 4 and 5 April already heralded significant changes to the political system that Mao built, even before the Chairman died physically. In fact, some viewed it as the beginning of "deMaoification" even before Mao was deceased. (54) The Chinese people had tired of the tumultuous politics that Mao loved; they hungered for stability and economic development. For them, Zhou Enlai, not Mao, best reflected their social, political, and economic interests. Perhaps Mao understood that Zhou's moderate politics and his support for the Four Modernisations threatened Mao's authority and popularity; hence his mistreatment of Zhou while the Prime Minister lived, his insulting treatment of Zhou after he passed away, and his refusal to allow large-scale mourning by the Chinese people.

In reflecting on this major crisis in Chinese politics, where the citizenry participated autonomously on a massive scale and demonstrated hostility to important members of the ruling elite, we can consider what triggered this explosion and whether it has any lessons for China's future. Several points stand out.

51. Tiewes and Sun say that Jiang Qing was the strongest advocate of sending in troops and quickly clearing the square, in part because so many of the wreaths attacked her. Fred Tiewes and Warren Sun, The End of the Maoist Era: Chinese Politics in the Twilight of the Cultural Revolution, 19721976, op. cit., pp. 479-480.

52. Garside describes the events in the square on 5 April. See Roger Garside, Coming Alive: China after Mao, op. cit., pp. 157-164

53. I believe that there are few photos of the riot in the West, as anyone with a camera had their film torn out. Fortunately, I did not go to the square on the $5^{\text {th }}$, so my film from the $4^{\text {th }}$ was not confiscated.

54. Claude Cadart and Chen Yingxiang, Les Deux morts de Mao Tsé-toung. Commentaires pour "Tian'an men l'Empourprée" de Hua Linshan (Mao Zedong's Two Deaths. Comments on Hua Linshan's "Now-turned Purple Tiananmen"), Paris, Éditions du Seuil, 1977. 


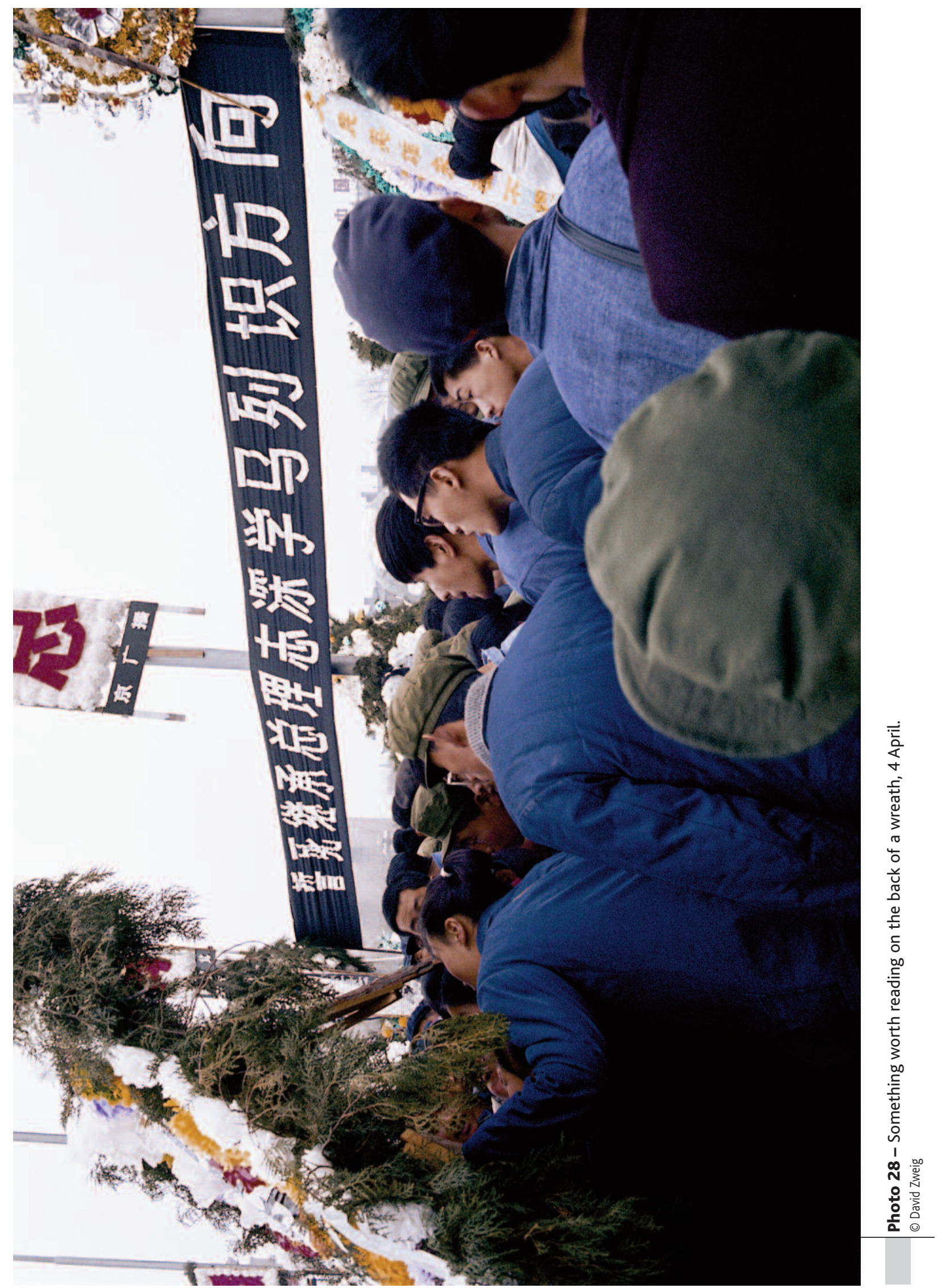




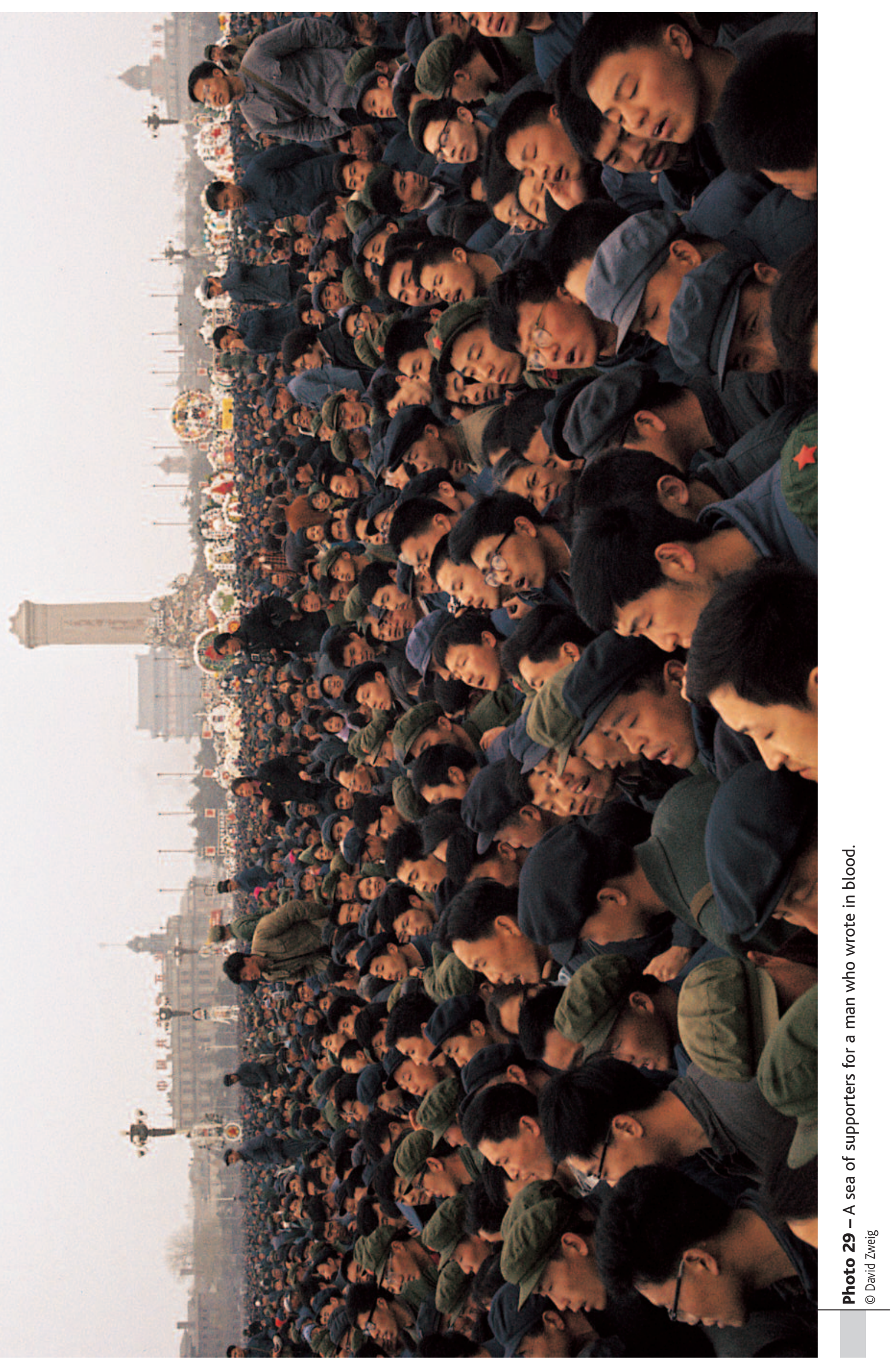




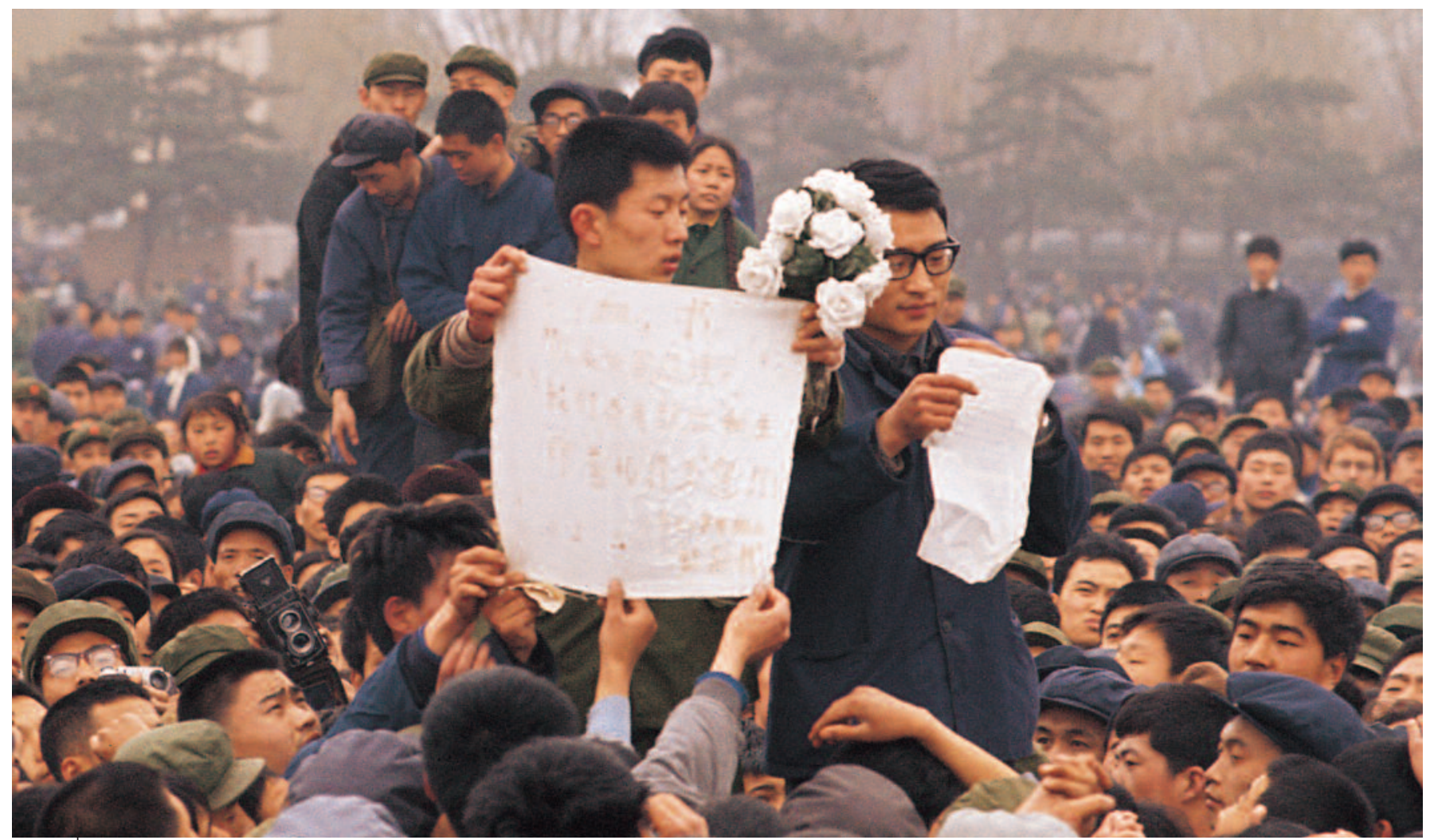

Photo 30 - The man who wrote in blood.

๑) David Zweig

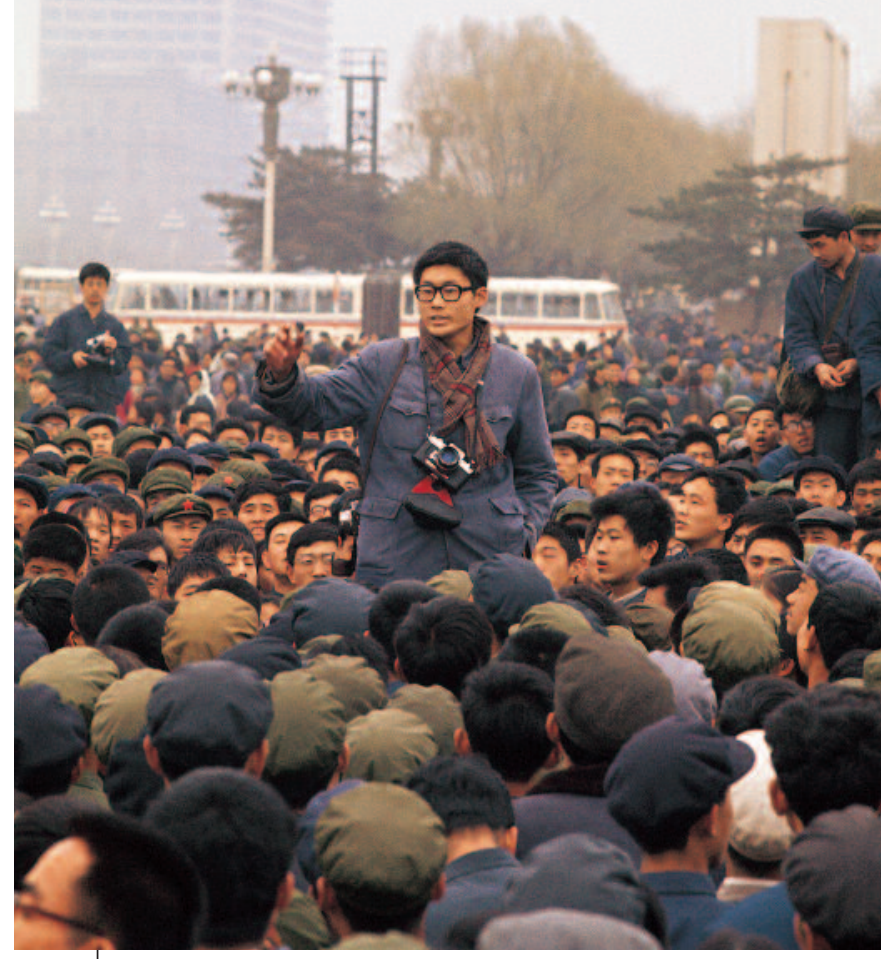

Photo 31 - Speaking for the interests of the elite. ๑) David Zweig

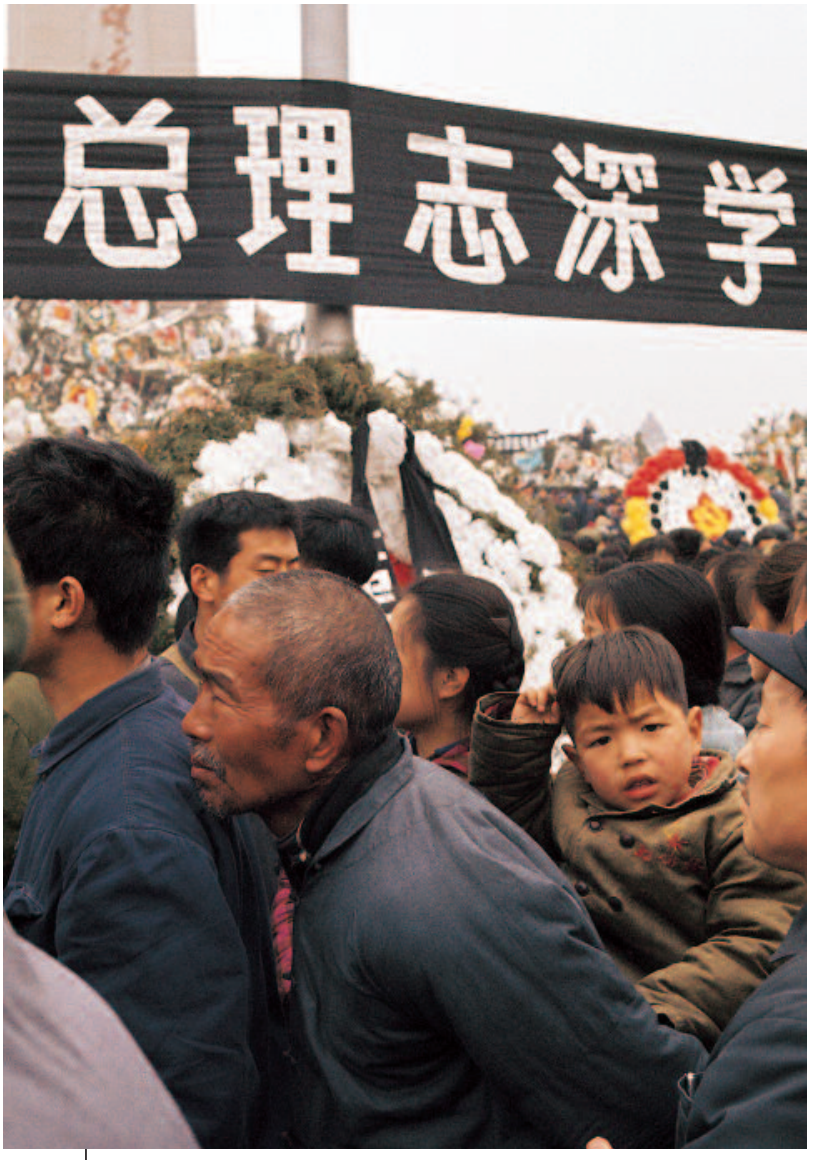

Photo 32 - An old man with his grandson. () David Zweig 


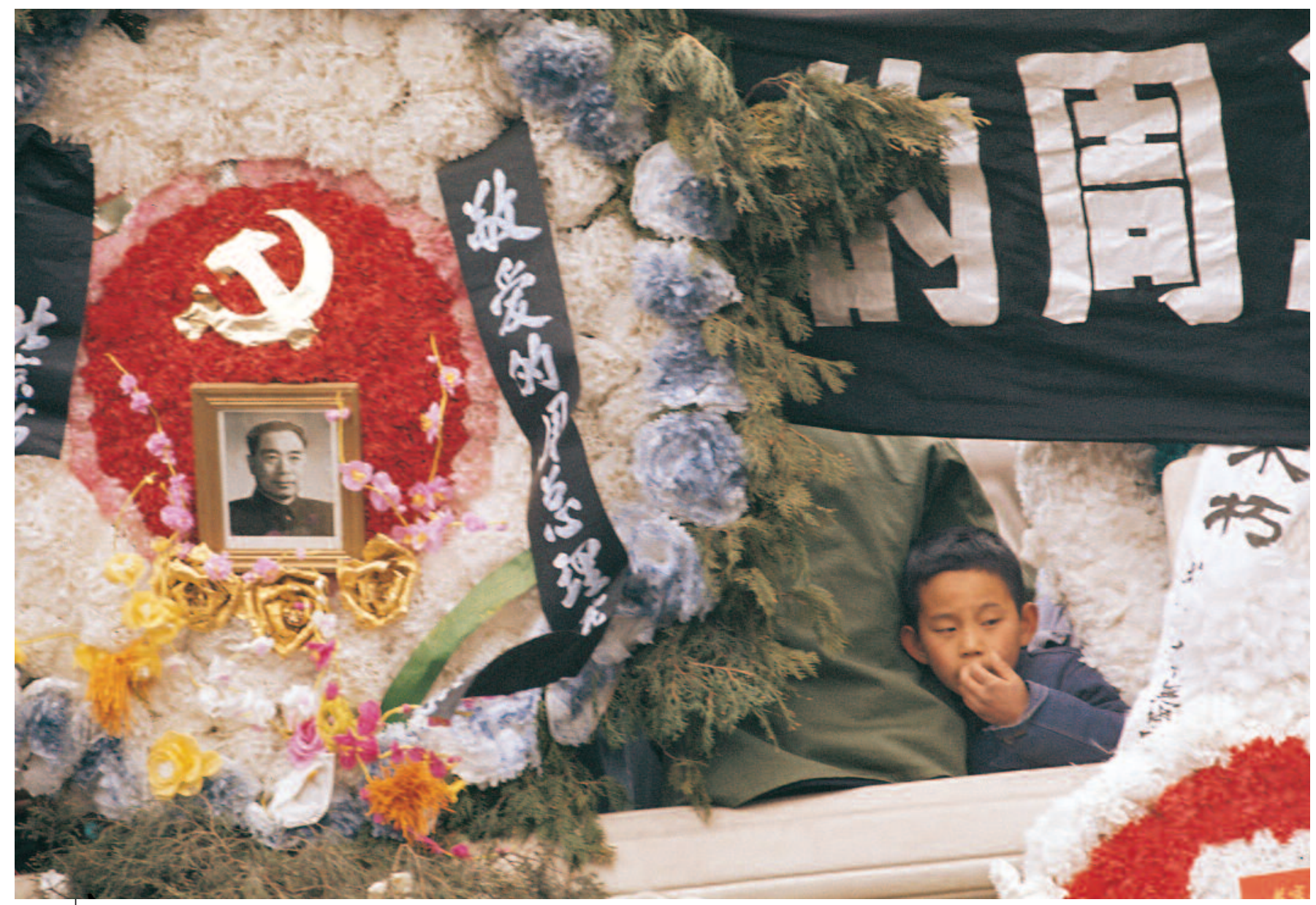

Photo 33 - A young boy ponders Zhou and China's future.

(๑) David Zweig

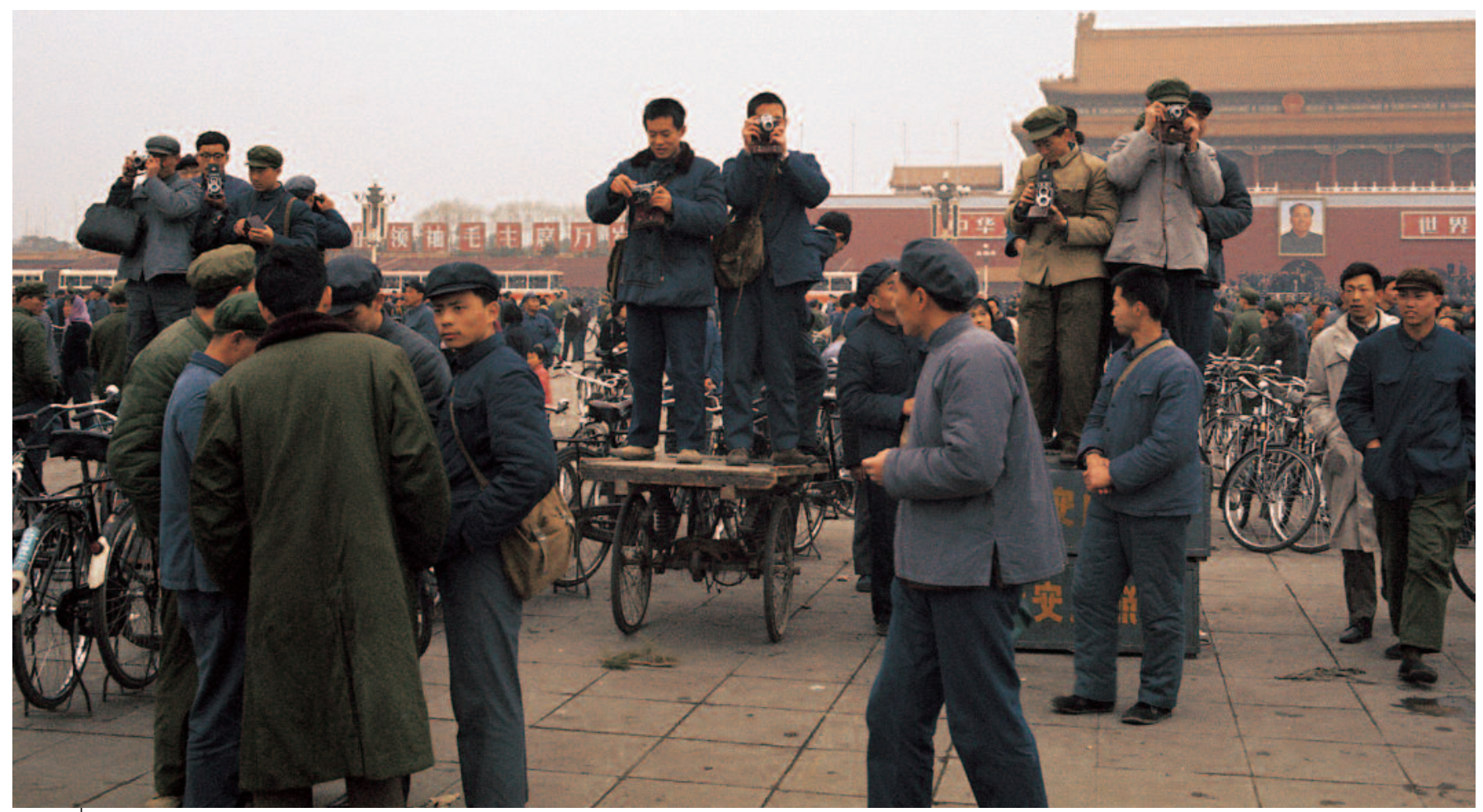

Photo 34 - Cameras clicking, but to what end?

(๑) David Zweig 

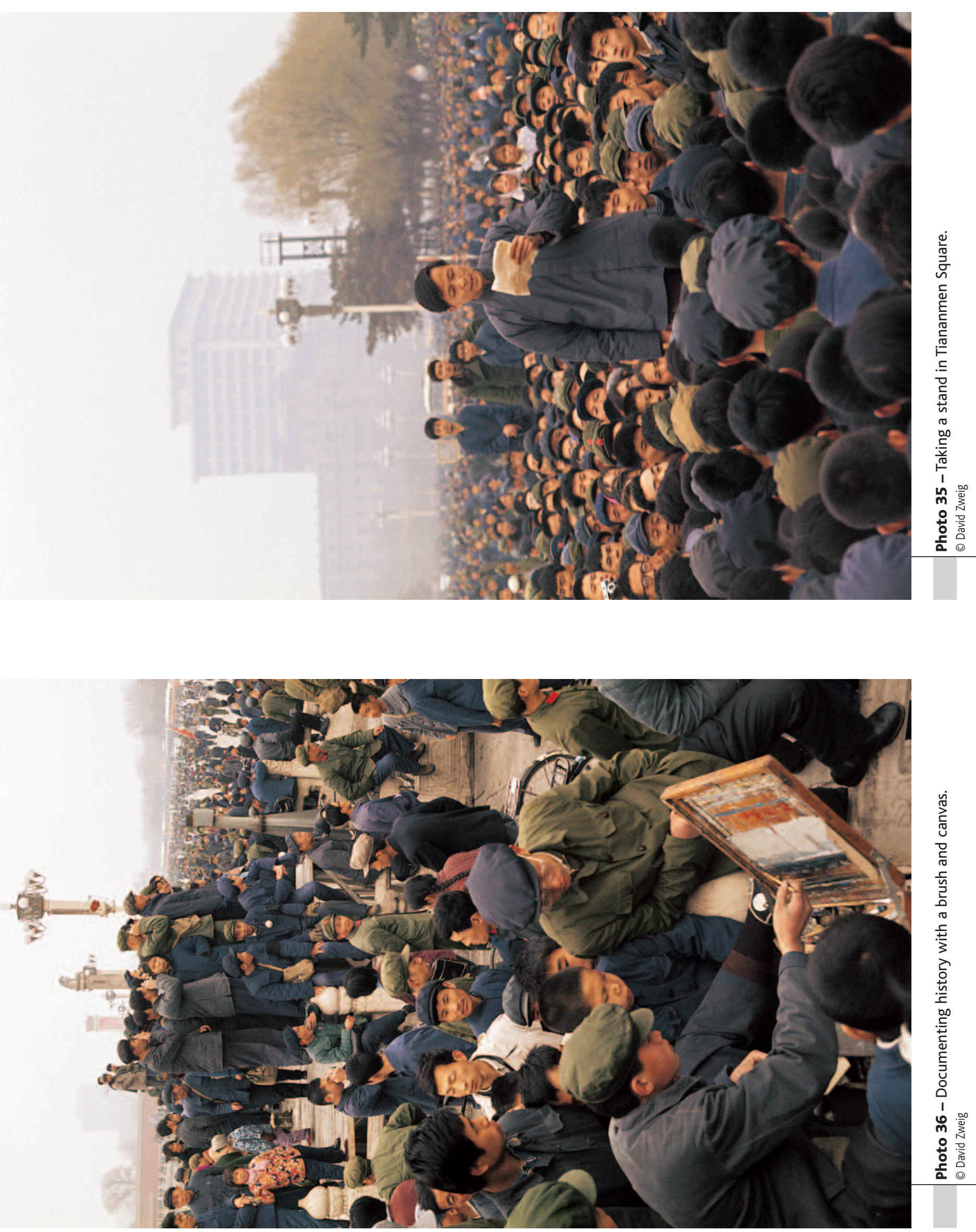

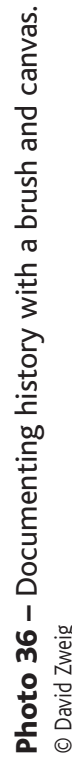




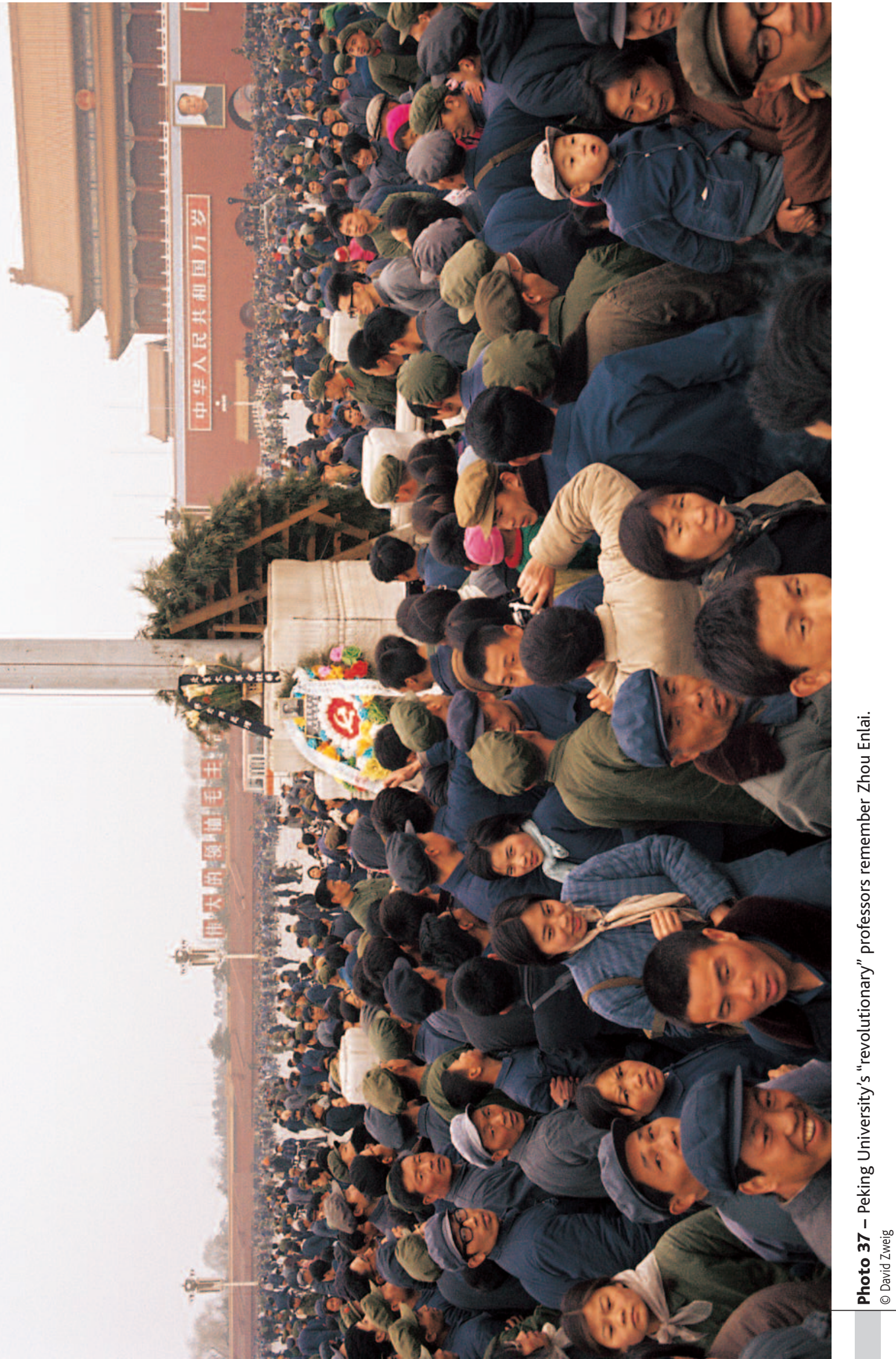


First, this was a time of leadership transition brought on by the death of Zhou Enlai. Mao's health was also fading rapidly, creating a political vacuum over which different factions would engage in fierce political combat. Intense factional struggle, in fact, a "no-holds-barred" battle for ultimate power, emerged, as both sides showed limited concern about civil innerparty struggle. In fact, the struggle ended only with the arrest of one of the key groups of protagonists.

Second, this period saw the coexistence of two opposing policy lines that both had a chance for ascendancy. A Leftist future for China, based on norms of the Cultural Revolution, was challenged by the possibility of China's own political spring. After the Fourth National People's Congress, Zhou's moderate line - based on the "Four Modernisations" - and Deng's "consolidation" program gained wide popularity, what Fenwick called "the arousal of unprecedented spontaneous popular response to the Gang's agenda." (55) In fact, many people hoped that Zhou and Deng's line would win. So when Mao intervened by attacking Deng's reform program, and the Politburo radicals and their allies moved into a dominant position, Chinese society struck a blow for rational politics, economic development, and social stability.

The same held true for the student protests of fall 1986 and the second Tiananmen crisis of 1989. The year 1986 began with a strong push from reformist forces. The summer of 1986 may have been the freest moment in post-1949 China. But at the Beidaihe Meeting in August that year, the CCP passed a resolution calling for the advancement of "spiritual civilisation" (jingshen wenming 精神文明), a code word for strengthening Party leadership and pro-communist behaviour.

For four months competing trends coexisted, as despite this manifestation of Leftist power, forces favouring serious political reform intensified, even from within the CCP. So, when political protests erupted in Hefei, much like the anti-Gang of Four protests in Nanjing in March 1976, students took to the street in Shanghai and Beijing, and in the latter case were arrested when they marched into Tiananmen Square.
June Fourth had the same feel. The $13^{\text {th }}$ Party Congress of fall 1987 had been the high point of political reform in the entire reform era. But Zhao Ziyang and the reform faction confronted deep trouble after the lifting of planned prices in summer 1988 triggered a popular panic. Li Peng, Yao Yilin, and other conservatives denounced Zhao for a liturgy of crimes. But the students, in response to the death and mistreatment of HuYaobang, challenged the Left in the CCP and brought on a political crisis. This time they occupied Tiananmen Square for almost a month before they were violently driven out. Today, China does not face a succession crisis. We hear few moderate voices from within the CCP. We see no deep factional struggle, and little room for political reform. Xi Jinping has proposed a radical economic program, but rather than face an obvious challenge from the "Left," Xi confronts only foot-dragging and policy resistance. Moreover, Xi's Third Plenum program has failed to galvanise Chinese society in the same way as Zhou Enlai and Deng's 1975 program or Zhao Ziyang and Hu Yaobang's vision for the 1980s. People may speculate about what could happen if Xi fails, but the patterns of the past suggest that a popular revolt is not on the horizon. Nor do communist systems have a history of purging the top leader. Nevertheless, as these pictures show, we should never underestimate the capacity of the Chinese people to find ways to strike a blow for reform.

I David Zweig is chair professor, Division of Social Science, Hong Kong University of Science and Technology, and director of the Center on China's Transnational Relations. He is senior research fellow of the Asia-Pacific Foundation, Vancouver, and vice president, Center on China and Globalization, Beijing. Academic Building 3386, Hong Kong University of Science and Technology, Kowloon, Hong Kong (sozweig@ust.hk). 